\title{
Tradiciones electivas. Cambio, continuidad y ruptura en historia intelectual ${ }^{*}$
}

Selective Traditions... Change, Continuity and Rupture in Intellectual History

\author{
Javier Fernández Sebastián \\ Catedrático de Historia del \\ Pensamiento Político en la \\ Universidad del Pais Vasco (UPV - \\ Bilbao/España) \\ E-mail: javier.fsebastian@ehu.es
}

Quisiera expresar mi agradecimiento a mis queridos colegas Andréa Slemian y João Paulo G. Pimenta por invitarme amablemente a presentar el texto que está en el origen de este artículo para ser discutido en el Fórum de la revista Almanack (UNIFESP, 6 de mayo de 2013). Mis sinceras gracias también a Fernando Nicolazzi y a Fábio Franzini por sus atinadas criticas y comentarios, asi como a todos los participantes en el debate. Permitaseme mencionar, por último, que este trabajo forma parte de las actividades del Grupo de Historia Intelectual de la Política Moderna IT615-13 (Gobierno Vasco) y del Proyecto de Investigación HAR2010-16095 (Gobierno de España).

\section{Resumen}

Este ensayo empieza por cuestionar ciertos lugares comunes sobre los pares dicotómicos modernidad/tradición, ruptura/continuidad, estereotipos que todavía circulan entre aquellos historiadores que contraponen frontalmente ambos polos, como si se tratase de factores radicalmente incompatibles, vectores mutuamente excluyentes. Para ello pone de relieve el carácter dinámico y la dimensión productiva de la tradición, entendida como ingrediente fundamental y mecanismo insustituible en los procesos de cambio e innovación intelectual. El artículo subraya que los tiempos modernos -y sus revoluciones- son un fecundo laboratorio de lo que el autor denomina "tradiciones electivas". Por medio de ellas, diversos actores colectivos en formación - partidos políticos y movimientos ideológicos, naciones, clases...- se autoconstituyen, dotándose de diferentes pasados ad hoc: del abigarrado almacén del pasado, sus ideólogos y líderes seleccionan ciertos personajes, acontecimientos y textos canónicos conformando con ellos identidades narrativas, corrientes históricas y trayectorias de larga duración en las que dichos actores se reconocen y se inscriben a sí mismos con vistas a legitimar sus proyectos de futuro. De ese modo, los modernos escogen sus supuestos predecesores, presentándose como sus epígonos. El enfoque da las "tradiciones electivas", sugiere este artículo, podría arrojar luz sobre determinados aspectos de la historia de las ideologías y de los movimientos políticos y sociales en los últimos siglos.

\footnotetext{
Abstract

This essay begins by questioning certain common places regarding such dichotomies as modernity vs. tradition, rupture vs. continuity, stereotypes still circulating among those historians who present a direct opposition between both poles, as if they were radically incompatible factors, mutually exclusive vectors. To this end, it emphasizes the dynamic nature and the productive dimension of tradition, understood to be a fundamental ingredient and irreplaceable mechanism in processes of change and intellectual innovation. The article underlines the fact that modern times and their revolutions - are a prolific laboratory of what the author calls "elective traditions". By means of these, diverse collective actors in the making - political parties and ideological movements, nations, classes, etcetera - build themselves, adopting different ad hoc pasts: from the variegated store of the past, their leaders and ideologists select certain characters, events and canonical texts with which they shape narrative identities, long-term historical currents and ongoing trajectories in which these actors identify themselves and to which they subscribe with a view
} 
to legitimizing their future projects. In this way, the moderns choose their purported predecessors, presenting themselves as their heirs. The focus of "elective traditions", this article suggests, might shed light upon certain aspects of the history of ideologies and of political and social movements in recent centuries.

Palabras-clave

tradición, modernidad, innovación, tradiciones electivas, historiografía, historia intelectual.

\section{Keywords}

tradition, modernity, innovation, selective traditions, historiography, intellectual history.

El propósito de este trabajo es problematizar un puñado de nociones usualmente presentadas como antitéticas -cambio vs. permanencia, innovación vs. tradición, ruptura vs. continuidad-, categorias dicotómicas de las que los historiadores y otros científicos sociales nos servimos con desenvoltura para dar cuenta de los procesos históricos, pero a las que en raras ocasiones prestamos atención en sí mismas.

Aunque, como se irá viendo en la bibliografía citada en este ensayo, no pocos hermeneutas y especialistas en filosofia de la historia -en el sentido crítico, no especulativo ni teleológico, que esta expresión ha adoptado en los últimos tiempos- han hecho de tales categorías un tema de debate, este no suele ser el caso del historiador ordinario. Dedicado a la investigación empírica sobre tal o cual periodo u objeto del pasado, este tipo de cuestiones teórico-metodológicas generalmente escapan a sus intereses, lo que muchas veces implica la reproducción y propagación perezosa de una serie de categorías de análisis que tienen mucho de estereotipado y son asumidas sin ninguna discusión previa sobre su validez o pertinencia.

Me parece, sin embargo, que también los historiadores corrientes, sin necesidad de ser expertos en teoria de la historia (como no lo es quien esto escribe), deberíamos detenernos alguna vez a recapacitar sobre tales asuntos. Consecuentemente, en las páginas que siguen me limito a plantear algunas reflexiones surgidas de mi propia práctica del oficio de historiador, en particular en el terreno de la historia político-intelectual.

Comenzaré por abordar algunas facetas de la dicotomía continuidad/ ruptura, centrándome en el binomio tradición/innovación referido especialmente a la historia intelectual.

Soy consciente de que el cambio y sus aporias constituye una vieja cuestión filosófica, una de las más arduas y discutidas desde la Antigüedad (es casi imposible tratar sobre el cambio sin referirse a un concepto tan escurridizo como lo es el de tiempo, y viceversa); razón de más para que mi pretensión no vaya más allá de aproximarme a algunos aspectos de esta vasta problemática atinentes a la disciplina de la historia (que no en vano se ha definido como "ciencia del cambio").

Más que para disipar dudas y apuntalar certezas, abrigo la esperanza de que estas páginas puedan servir para remover preconcepciones simplistas, muy arraigadas todavía en un sector del gremio de los historiadores. 
Resulta revelador a este respecto el perfil evolutivo de la presencia de las voces innovación y tradición en los textos en español a lo largo de los tres últimos siglos. Mientras que el índice de ocurrencias de los dos términos en el caudal léxico parece haber seguido una marcha similar, ascendente en ambos casos, la valoración de cada uno de ellos habría cambiado de signo, siguiendo trayectorias cruzadas. Innovación, hoy dia una estrella refulgente del vocabulario económico y tecnológico, político y social, fue por mucho tiempo una palabra negativamente connotada. Tradición, por el contrario, ha descendido desde una valoración eminente en tiempos pasados hasta posiciones bastante mediocres en la actualidad.

2

MARIANA, Juan de. Historia general de España [1601]. In:__ Obras. Madrid: Atlas, 1950. Vol. 1, p. LII.

3

LOVEJOY, Arthur 0. La gran cadena del ser. Historia de una idea. Barcelona: Icaria, 1983. p. 314 y ss.

KOSELLECK, Reinhart. Historie/Geschichte. In: BRUNNER, Otto; CONZE, Werner y KOSELLECK, Reinhart (Eds.). Geschichtliche Grundbegriffe: historisches Lexikon zur politisch-sozialen Sprache in Deutschland [en adelante GG]. Stuttgart: Klett-Cotta, Vol. 2, 1975. p. 593-717; versión española de GÓMEZ RAMOS, Antonio. historia/Historia. Madrid: Trotta, 2004.

5

MEINECKE, Friedrich. El historicismo y su génesis. México: FCE, 1943. WITTKAU, Annette. Historismus: Zur Geschichte des Begriffs und des Problems. Gotinga: Vandenhoeck \& Ruprecht, 1992. IGGERS, Georg G. The German Conception of History: The National Tradition of Historical Thought from Herder to the Present. Middletown Ct.: Wesleyan University Press, 2. ed. revisada, 1983; Comments on F. R. Ankersmit's Paper 'Historicism: An Attempt at Synthesis'. History and Theory, Vol. 34, n. 3, 1995. p. 162-167. Historicism: The History and Meaning of the Term. Journal of the History of Ideas, Vol. 56, n. 1, 1995. p. 129-152. OEXLE, Otto Gerhard. Geschichtswissenschaft im Zeichen des Historismus. Studien zu Problemgeschichten der Moderne. Gotinga: Vandenhoeck y Ruprecht, 1996. SMITH, Leonard S. Religion and the Rise of History. Martin Luther and the Cultural Revolution in Germany, 1760-1810. Cambridge: James Clarke \& Co, 2010. OLSEN, Niklas. History in the Plural. An Introduction to the Work of Reinhart Koselleck. Nueva York y Oxford: Berghahn Books, 2012. Sobre este último libro, en relación con las cuestiones aqui tratadas, puede verse mi reseña: FERNÁNDEZ SEBASTIÁN, Javier. Against History (in the Singular). Contributions to the History of Concepts, Vol. 7, n. 2, 2012, p. 133-142.
Desde el enfoque indicado subrayaré, a la luz de las contribuciones de diversos autores, la dimensión productiva y dinámica de la tradición, saliendo al paso de aquellas interpretaciones que, apoyándose a menudo en las teorías de la modernización -e incurriendo a veces en cierto malentendido ideológico que confunde tradición y tradicionalismo-, menosprecian el papel de la tradición en los procesos de innovación intelectual. Trataré de iluminar algunas facetas de las poliédricas relaciones entre modernidad y tradición, mostrando que -contra lo que suele creerse- los tiempos modernos son especialmente prolíficos en tradiciones (en cierto tipo de ellas).

Tal vez no sea ocioso empezar constatando que la relevancia política y filosófica del tema, lejos de ser una constante ahistórica, es una variable cultural sujeta a grandes oscilaciones. Sin salirnos de nuestro ámbito cultural, la visibilidad que el cambio y la innovación han alcanzado en nuestras sociedades no tiene parangón con el lugar mucho más modesto que a estas categorías les estaba reservado en épocas anteriores. ${ }^{1}$

Por muchos siglos la idea de que el orden del mundo, la verdad y la propia naturaleza humana eran esencialmente los mismos en todos los tiempos y lugares parece haber dominado ampliamente los espíritus. Teniendo en cuenta esa homogeneidad sustancial de la razón y de las experiencias posibles de los seres humanos, la aplicabilidad universal e intemporal de las enseñanzas morales que se desprendian de aquel tipo de historia ejemplarizante estaba fuera de duda. "[L]os tiempos pasados y los presentes semejables son, y como dice la Escritura, lo que fue eso será", escribe Juan de Mariana al comienzo de su Historia general de España. ${ }^{2}$ Todavía durante buena parte del siglo XVIII la mayoría de los ilustrados sostuvieron posiciones universalistas e intemporales en moral y en filosofía, si bien la eclosión de la conciencia histórica empezó a desafiar las viejas imágenes fijistas de la gran cadena de los seres: la infiltración paulatina de la temporalidad terminaría por corroer y colapsar a comienzos del siglo XIX aquel inmemorial esquema jerárquico de comprensión del mundo. ${ }^{3}$

A partir de entonces, una nueva noción de historia ${ }^{4}$-y la renovada disciplina a ella asociada- lograria gradualmente arrumbar anteriores visiones de un mundo básicamente iterativo. El desarrollo del historicismo y la moderna conciencia de la historicidad -y de la lingüisticidad- del mundo vinieron a enriquecer y a complejizar extraordinariamente las ideas acerca del cambio. Desde Kant y Hegel a Heidegger y Gadamer, la reflexividad creciente aplicada no solo al análisis del cambio sino también a las categorías y procedimientos para su intelección condujo a una, cada vez más, extensa y profunda historización del mundo (pensamiento incluido). Un proceso finalmente abocado en el siglo XX, tras una critica severa al historicismo del novecientos, a su replanteamiento sobre nuevas bases. Mientras que aquel primer historicismo alemán habria traído consigo desde mediados del siglo XVIII la temporalización de la historia, la nueva hermenéutica histórica y filosófica del siglo XX Ilevaria a la historización del historicismo mismo, que desde dentro de la historiografía, con la semántica histórica al estilo de Koselleck, se toma finalmente en serio la historicidad del propio pensamiento histórico. ${ }^{5}$ 
6

VEYNE, Paul. Cómo se escribe la historia. Ensayo de epistemología. Madrid: Fragua, p. 181, 1972.

7

BRAUDEL, Fernand. Histoire et Science sociales. La longue durée. Annales E.S.C., Vol. 13, n. 4, 1958. p. 725-753; KOSELLECK, Reinhart. Futuro pasado. Para una semántica de los tiempos históricos. Barcelona: Paidós, 1993; REVEL, Jacques (ed). Jeux d'échelles. Le micro-analyse à l'expérience. Paris: Seuil-Gallimard, 1996.

8

Interesa subrayar que un mismo conjunto de fenómenos y de experiencias puede ser encapsulado y descrito de muy diferentes maneras dependiendo de los conceptos y lenguajes utilizados: STEDMAN JONES, Gareth. Lenguajes de clase. Estudios sobre historia de la clase obrera inglesa (1832-1982). Madrid: Siglo XXI, 1989. p. 197.

9

MUNSLOW, Alun, y ROSENSTONE, Robert A. Experiments in Rethinking History. Londres: Routledge, 2004. p. 11.

10

FERNÁNDEZ SEBASTIÁN, Javier. Entre el Espiritu Santo y el espiritu del siglo. Sobre la Constitución de las Cortes y el primer liberalismo hispano. Anthropos, n. 236, 2013. p. 55-75.
Cambio histórico y cambio conceptual: percepción y retórica

Como resultado de estos debates, un amplio cuerpo de literatura histórica y filosófica, producida sobre todo en la segunda mitad del siglo XX, ha hecho que el historiador actual sea mucho más consciente de que el cambio no es algo exterior y "objetivo" que afecta únicamente a los agentes del pasado. También el historiador, el filósofo o el politólogo están localizados en un contexto y forman parte de un mundo en devenir, como la historia de la historiografía y de las ciencias sociales no han dejado de señalar. Ahora bien, puesto que tanto los objetos observados como el observador son sujetos móviles, la omnipresencia del cambio histórico nos obliga a asumir la inevitable provisionalidad y caducidad de nuestros esquemas interpretativos. Así, la historiografía pudiera ser contemplada, en palabras de Paul Veyne, como un inacabable tira y afloja "entre una verdad siempre cambiante y conceptos siempre anacrónicos".

Hoy ha llegado a ser evidente que la captación de las diferencias y discontinuidades - ¿qué otra cosa es el cambio para el historiador sino la distinción, registro y especificación de tales diferencias sobre una secuencia temporal?- tiene una base epistémica. Como han mostrado algunos trabajos bien conocidos de Braudel, Koselleck o Revel, ${ }^{7}$ la llamada "realidad social" no es la misma cuando es observada desde diferentes escalas temporales o espaciales, o simplemente desde distintas categorias o niveles de análisis. ${ }^{8}$ Lejos de ser una variable independiente, el cambio sería pues una cualidad compleja y elusiva, con una doble dimensión ontológica y cognitiva. Privado de la posibilidad de suturar por completo la insalvable distancia "entre lo que una vez ocurrió [y significó] y lo que significa ahora", ${ }^{9}$ el historiador no tiene más remedio que reconocer que su particular aprehensión y graduación del cambio no es solo el fruto inmediato de la objetivación de los preterita sometidos a análisis; depende también, en gran medida, de su mirada y de las lentes interpretativas de que se sirve.

El trasfondo de algunos enconados debates referentes a la historia contemporánea de España tiene que ver precisamente con la disparidad de filtros categoriales utilizados por unos y por otros para medir el cambio (esto es, para captar y ordenar las diferencias y su ritmo de aparición sobre una secuencia temporal). Recientemente, con ocasión del bicentenario de la Constitución de 1812, varios grupos de historiadores han hecho valer sus serias discrepancias acerca del grado de "rupturismo" del primer liberalismo español. Pues bien, a mi juicio, esas discrepancias tienen que ver sobre todo con el recurso a dos criterios bastante distintos para evaluar el novum de la revolución española de 1810: para unos, la clave está en la proclamación por las Cortes de Cádiz de la soberanía nacional como principio legitimador, potencialmente constituyente; para otros (más apegados al canon de la Revolución francesa), una verdadera ruptura hubiera debido implicar la superación de la vieja cultura política corporativa y jurisdiccional plenamente vigente todavía a comienzos del siglo XIX.10

Muchas diferencias de apreciación derivan del simple hecho de que las pautas políticas, económicas, morales o religiosas que sirven de fundamento para la valoración de los sucesos han variado enormemente a lo largo del tiempo. Y no ser conscientes de ello puede llevarnos a incurrir en ese "pecado mortal del historiador" -Febvre dixit- que es el anacronismo, ya sea moral o cognitivo. En muchos aspectos un liberal progresista de la primera mitad del XIX -no digamos un ilustrado del siglo anterior- parecería sin duda un conservador a los ojos de un demócrata de después 
11

Obviamente las concepciones y percepciones a las que aqui me refiero son aquellas que los historiadores, basándonos en nuestra interpretación de las fuentes, les atribuimos a los agentes desaparecidos que son objeto de nuestro estudio, oportunamente "traducidas" al lenguaje de los lectores actuales.

12

En 1998, cien años después del llamado desastre de 1898, muchos especialistas en el periodo llegaron a la conclusión de que la reacción de las élites españolas de finales del siglo XIX ante la derrota en la guerra contra los Estados Unidos fue un caso de percepción exagerada, y que aquellos acontecimientos -la pérdida de las últimas colonias: Cuba, Puerto Rico y Filipinas- no fueron en realidad tan catastróficos y decisivos para España como se pensó en el momento en que sucedieron.

13

RICCEUR, Paul. La memoria, la historia, el olvido. Madrid: Trotta, 2003. p. 441-452; KOSELLECK, Reinhart. Futuro pasado. Op. Cit. p. 186 y ss.

14

Según parece, algunos estudios antropológicos han mostrado que la "dosis de novedad" [quantum innovationis] que nuestra mente y nuestros sentidos son capaces de asimilar es limitada: PALOS, Joan Lluis y CARRIÓINVERNIZZI, Diana. El estatuto de la imagen en la Edad Moderna. In: La historia imaginada. Construcciones visuales del pasado en la Edad Moderna. Madrid: Centro de Estudios Europa Hispánica, 2008. p. 18. de la Segunda Guerra Mundial. Mientras que cualquier especialista en la Europa de la primera Edad Moderna sabe que para entender cabalmente la Monarquía española de aquel tiempo no deberiamos separar la política de la religión, esa misma actitud ideológica a finales del siglo XIX sería conceptualizada como integrismo. Pero eso no nos autoriza a considerar extemporáneamente "conservador" al liberal progresista decimonónico ni a calificar de "integrista" a la Monarquía católica de los siglos XVI y XVII. Son solo un par de ejemplos de los peligros que acechan al historiador que, poco atento a la historicidad de los marcos mentales y de las fuentes que maneja, supone erróneamente que el tiempo histórico es un medio intelectualmente diáfano -un espacio semántico continuo e indiviso- y que, en consecuencia, todo puede medirse por el mismo rasero.

El constante vaivén entre las concepciones -y las percepciones- de historiadores e historiados ${ }^{11}$ es importante también a la hora de estimar el alcance de las mutaciones sufridas por una sociedad en el pasado. Asi, a varias décadas o siglos de distancia de los hechos, el historiador podría llegar a la conclusión de que las gentes de determinada época habrian sobreestimado la trascendencia de ciertos sucesos que, en su momento, a los actores les parecieron altamente relevantes pero que, a la vista de las consecuencias y acontecimientos posteriores, pudo luego comprobarse que no lo fueron tanto; ${ }^{12} \mathrm{y}$, al revés, esas mismas gentes podrian haber menospreciado otros acontecimientos o procesos que a la larga se habrian revelado mucho más decisivos. Puesto que el cambio está en función del tiempo, la distancia temporal permite descubrir transformaciones que no es posible apreciar cuando apenas se están incoando. Gracias a su visión retrospectiva, el historiador percibe continuidades y discontinuidades insospechadas para los propios agentes. Ciertamente, como afirma el viejo dictum, "los tiempos mudan las cosas"; pero, además, el tiempo altera la percepción que teniamos de la profundidad, el cómo y los porqués de los cambios sociales y políticos de épocas pasadas. No en vano, como ha subrayado Ricœur, la cadena de interpretaciones y reinterpretaciones de unos mismos hechos a lo largo del tiempo es, en sí misma, "generadora de sentido".13

Lo que va dicho puede ser aplicado mutatis mutandis a la historia intelectual, y especificamente al estudio del cambio conceptual (después de todo, el cambio conceptual es una dimensión y una parte activa de los cambios políticos y sociales). La detección de cambios semánticos significativos ocurridos en el pasado siempre tiene lugar al menos en un doble contexto: el de la época estudiada (al cual es posible acceder a través de las fuentes), y el del historiador-intérprete. Pero naturalmente "nuevo" y "viejo" son etiquetas caducas y relativas. Lo que una vez pareció nuevo, en cierto momento empezó a ser visto como viejo, y es muy habitual que partiendo de elementos antiguos llegue a conformarse algo que por un tiempo fue percibido como novedoso.

Por lo demás, tanto en el pasado como en el presente (también desde el particular presente que, en la mirada del historiador, se vuelve hacia el pasado) la percepción de la novedad parece estar sujeta a umbrales máximos y mínimos. Al igual que sucede con la percepción sensorial, por encima o por debajo de cierta proporción o magnitud -una especie de "coeficiente de innovación"- las modificaciones, o bien pasarian inadvertidas (por defecto) o bien resultarían ininteligibles (por exceso). ${ }^{14} Y$, puesto que la caracterización de algo como nuevo supone siempre una desviación respecto de las expectativas del observador en un contexto dado (lo nuevo, 
LUHMANN, Niklas. La ciencia de la sociedad. Barcelona: Anthropos, 1996. Sobre la cuestión del acontecimiento como percepción de un cambio véase POMIAN, Krzysztof. L'ordre du temps. Paris: Gallimard, 1984. p. 16 y ss.

ANKERSMIT, Frank R. Meaning. Truth and Reference in Historical Representation. Ithaca: Cornell University Press, 2012

17

KOSELLECK, Reinhart. Futuro pasado. Op. Cit. p. 270-271; WHITE, Hayden. Metahistoria. La imaginación histórica en la Europa del siglo XIX. México: FCE, 1992

18

LORENZ, Chris. Can Histories be True? Narrativism, Positivism, and the 'Metaphorical Turn'. History and Theory, Vol. 37, n. 3, 1998. p. 309-329. en historia, equivale a la epifanía del acontecimiento, i. e., a la irrupción súbita de lo insólito, de lo inesperado, en la secuencia de lo acostumbrado), las transformaciones que llevan el sello de la novedad suponen estructuras semánticas y temporales previas sobre las cuales aparecen elementos imprevisibles que no encajan del todo en ese marco de comprensión, compuesto de experiencias y expectativas (un marco que, pese a todo, es el que le da sentido a los cambios sobrevenidos). ${ }^{15}$

De modo que la captación del cambio conceptual no es -como pudiera pensarse ingenuamente- una mera constatación empírica "objetiva" de las transformaciones sufridas por los conceptos en algún momento del pasado, sino que depende en alto grado tanto de la reconstrucción de las redes semánticas imperantes en aquel momento distante como de los instrumentos utilizados más tarde para aprehender dichas transformaciones (instrumentos que tampoco escapan a la historia, puesto que han sido forjados en contextos, lugares y circunstancias cognoscitivas dadas). El cambio, en suma, no es un simple dato que viene dado por "lo que sucede en el mundo" -o por lo que en cierto momento sucedió-, sino que más bien es moldeado de acuerdo con nuestras perspectivas, interpretaciones y representaciones cambiantes de aquellos sucesos, ocurrencias y discursos (incluyendo las concepciones subyacentes de la temporalidad que enmarcan dichas perspectivas).

Vistas así las cosas, una gran parte del cambio histórico distaría de ser un reflejo pasivo de la sucesión de res gestae y pasaría a ser un efecto dinámico construido no solo por la relación -ella misma cambiante- entre presentes y pasados, sino también producido y amplificado por las técnicas retóricas y los tropos de los artífices de las historiae rerum gestarum (que siempre escriben en presente, aunque sus escritos vayan a su vez irremisiblemente hundiéndose poco a poco en el pasado). Más que una característica inmanente del "pasado en si", el cambio sería pues un atributo de la representación historiográfica de ese pasado. ${ }^{16}$

Puesto que el pasado, como realidad factual, se ha desvanecido para siempre, toda interpretación historiográfica en cierto modo "recrea", reconstruye a partir de las fuentes una representación de las experiencias acontecidas $y$, en este sentido, se sirve de armas literarias no muy diferentes a las de la ficción. Al historiador le es necesario "fingir" realidades históricas desaparecidas produciendo retóricamente efectos de sentido; entre ellos, aquellos efectos que destacan lo que hay de tradicional o de innovador en los sucesos, situaciones o estructuras que inserta en su relato; en ese sentido el historiador se ve obligado a servirse de "ficciones perspectivistas", de recursos poéticos y de tropos. ${ }^{17}$

Eso no quiere decir, desde luego, que la historiografía sea un mero artificio literario, carente de toda ligazón o dependencia con las "realidades" desvanecidas del pasado. Como señaló hace años Chris Lorenz, criticando el "narrativismo metafórico" de Hayden White y Frank Ankersmit, el trabajo del profesional de la historia no se reduce a la redacción más o menos inspirada e imaginativa de textos historiográficos. El trabajo de investigación que precede a dicha escritura y el control intersubjetivo posterior por parte de la comunidad de historiadores sobre el valor de verdad de los hechos o procesos históricos analizados son prácticas disciplinares que -aunque "la verdad" no sea ya lo que solía ser- fijan ciertos límites más o menos estrechos a la imaginación historiográfica. ${ }^{18}$ Bastará recordar en este punto que Koselleck, el mismo autor que, como acabamos de ver, 
19

Cf., por ejemplo, KOSELLECK, Reinhart. Futuro pasado. Op. Cit. p. 201.

20

Multiplicidad de interpretaciones rivales que para Macintyre constituyen un sintoma de la crisis epistemológica por la que atraviesa la sociedad moderna: MACINTYRE, Alisdair. Epistemological Crises, Dramatic Narrative and the Philosophy of Science. The Monist, Vol. 60, n. 4, 1977. p. 458.

21

Me refiero aqui a un texto metodológico tan conocido como: SKINNER, Quentin. Meaning and Understanding in the History of Ideas. History and Theory, Vol. 8, n. 1, 1969. p. 1-53.

22

En el mundo anglófono se usan también otras expresiones, algunas de ellas muy recientes (game-changer, ground-breaking, cutting-edge), que enfatizan la innovación o la capacidad para introducir nuevos factores que cambian radicalmente el planteamiento de un problema. También es muy común la metáfora del despegue (take-off), que los trabajos de W. Rostow popularizaron en los años sesenta en la historia económica.

23

BURKE, Peter. Introduction: Concepts of Continuity and Change in History. In: (ed.) The New Cambridge Modern History: Companion volume. Cambridge: CUP, 1979. p. 9-10. reconocia paladinamente que el historiador se sirve de ficciones y efectos literarios de puesta en perspectiva, enfatizó muchas veces a lo largo de su obra lo que llamó el "derecho de veto" de las fuentes. ${ }^{19}$

Tales recursos y estrategias retóricas, sin duda imprescindibles en cualquier rama de escritura de la historia, resultan particularmente relevantes en el caso de la historia intelectual. Pues, naturalmente, dependiendo del prisma categorial y de los esquemas narrativos de que se sirva, el historiador del pensamiento ve y describe unas cosas $u$ otras. Las lentes y figuras retóricas utilizadas permiten no solo proponer múltiples interpretaciones de ciertas figuras eminentes del pensamiento (de Maquiavelo, Suárez o Hobbes, por ejemplo), ${ }_{1}^{20}$ sino trazar vínculos entre autores o formaciones intelectuales del pasado -filiaciones y cambios de rumbo; genealogías, superposiciones, antagonismos, puntos de ruptura y líneas de continuidad-, componiendo de ese modo auténticas identidades narrativas. Asi, por referirme a algunas etiquetas historiográficas asociadas a historiadores bien conocidos de la teoría política, podríamos analizar los instrumentos heuristicos y los dispositivos lógicos que subyacen al "individualismo posesivo" de Macpherson, al "humanismo cívico" o al "republicanismo clásico" de Pocock y de Skinner, a la "cultura politica de la generalidad" de Rosanvallon, etc. Algunos de estos autores han mostrado convincentemente, por otra parte, que, si seguimos una metodología inadecuada, la percepción de las secuencias, influencias y corrientes intelectuales puede resultar muy distorsionada, dando lugar a ilusiones de continuidad retrospectivas (por ejemplo, a genealogías apócrifas o a falsas anticipaciones y prolepsis). ${ }^{2}$

En todo caso, y sin que su uso implique necesariamente incurrir en tales errores, el historiador intelectual tiene a su disposición un rico vocabulario para representar el cambio y acentuar rupturas y continuidades. Las impresiones de ruptura o de continuidad son producidas narrativamente por medio de diversos recursos literarios. Entre estos, los historiadores del pensamiento político somos particularmente aficionados a ciertas imágenes y tropos que se han vuelto lugares comunes en la jerga gremial. "Cuestión perenne" (perennial problem), "corriente" o "línea de pensamiento", "hilo conductor" son -o eran hasta hace poco- expresiones estereotipadas para enfatizar la continuidad de un problema, continuidad que se expresa también a través de metáforas lexicalizadas -que han dejado de percibirse como tales- tan habituales como filo rosso o leitmotiv. Muchas de esas metáforas historiográficas -como la del río o el camino que casi invariablemente desemboca en el presente- comportan toda una teleología de fondo.

Por otro lado, cuando tratamos de subrayar momentos de cesura, ruptura o discontinuidad utilizamos metáforas como parteaguas (watershed), hito (landmark), jalón (milestone), quiebra, giro o punto de inflexión (turning point); también otras expresiones aún más rotundas, como cuando señalamos que tal texto o tal acontecimiento supuso una "ruptura epistemológica", que representó "el fin de un mundo", que marcó "un antes y un después", o que tras él "ya nada sería igual."22 $E$ incluso en ocasiones recurrimos a expresiones tan contundentes como tabula rasa, ex nihilo, ex novo, desde cero (from scratch), y otras similares para resaltar situaciones 0 momentos de creación absoluta, en las que algo parece surgir de la nada. ${ }^{23}$

No es raro que la retórica académica abuse de este tipo de expresiones. Puesto que todo escrito en el que se ofrecen los resultados de una investigación -desde un modesto artículo hasta una sesuda tesis doctoral- se presenta generalmente como una contribución relevante al 
24

Un ejemplo reciente de este tipo de obras, muchas de las cuales de manera característica aspiran a descubrir el "verdadero" origen del mundo moderno, podría ser el libro de GREENBLATT, Stephen. The Swerve: How the World Became Modern. Nueva York: W. W. Norton, 2011.

25

FURET, François. Faire de l'histoire. Paris: Gallimard, Vol. 1, 1976. p. 54.

26

Gadamer ha insistido, tanto en el plano de la estética como en el fenomenológico (siguiendo en este caso a Husserl), en que la "pretensión de continuidad" caracteriza la autocomprensión de la vida humana, también en lo que se refiere a la más inmediata temporalidad existencial; y algo parecido sucede en el plano colectivo, de modo que incluso el poeta más inspirado o el inventor más genial están insertos en redes y tradiciones que les trascienden, de las cuales proviene una parte importante de su creatividad (GADAMER, Hans-Georg. Verdad y Método. Fundamentos de una hermenéutica filosófica. Salamanca: Sígueme, 1988. p. 107 y ss., 137 y ss., 166-167, 180 y 309 . Hablando de la originalidad de los poetas y del papel fundamental de la tradición, T. S. Eliot sostuvo muchos años antes opiniones muy semejantes: véase su clásico ensayo: ELIOT, T.S. Tradition and the Individual Talent [1919]. In Selected Essays. Londres: Faber and Faber, 3. ed., 1951. p. 13-22.

27

Al separarse de España, algunos criollos hispanoamericanos trataron de enlazar con el lejano pasado precolombino, presentando la independencia de las jóvenes repúblicas como el reverso de la conquista: una vez más, la ruptura parecia obedecer a un imperativo de continuidad. EARLE, Rebecca. The Return of the Native: Indians and Myth-Making in Spanish America, 1810-1930. Durham/Londres: Duke University Press, 2008. También los liberales peninsulares imaginaron el naciente constitucionalismo como un retorno a las antiguas libertades hispanas: FERNÁNDEZ SEBASTIÁN, Javier. A Distorting Mirror: The Sixteenth Century in the Historical Imagination of the First Hispanic Liberals. BalzanSkinner Lectures and International Conferences, Romantic Liberalism in Southern Europe, c. 1820-1850. Faculty of History at the University of Cambridge and CRASSH, 26/04/2013. Algo parecido sucedió en otros muchos momentos y lugares, desde la Alemania del Estado nacional unificado de 1871 (LANGEWIESCHE, Dieter. ¿Qué quiere decir "inventar la nación"? La historia nacional como artefacto o La interpretación de la historia como lucha por el poder. In: MILLÁN, Jesús y ROMEO, Maria Cruz, (eds.) La época del Estado-nación en Europa. Valencia: Universitat de València, 2012. p. 52-53 y 57) hasta la proclamación de la República en China tras el ocaso del Imperio (RÜSEN, Jörn. Tradition: A Principle of Historical Sense-Generation and its Logic and Effect in Historical Culture. History and Theory, Vol. 51, n. 4, 2012. p. 48-49). desarrollo del saber, sus autores tienden a enfatizar los aspectos innovadores, subrayando el conocimiento nuevo que su aportación viene a añadir al acervo científico en el campo de que se trate. En ese contexto, no es infrecuente que los científicos exageren la novedad de sus descubrimientos y propuestas. Su trabajo no se limitaría a llenar una laguna, a matizar la visión dominante de un determinado tema, o a proponer una interpretación alternativa de un fenómeno ya conocido, sino que con cierta frecuencia el autor se esfuerza en persuadir a los lectores de que su investigación o su enfoque supone un cuestionamiento sustancial de todas las aproximaciones anteriores a ese mismo objeto de estudio.

El discurso de la innovación presenta algunas caracteristicas especiales en el campo de la historia intelectual. En este terreno esta retórica puede aplicarse por partida doble: no solo para enfatizar la novedad de las aportaciones de quien escribe, sino también para señalar rupturas drásticas en las corrientes de pensamiento del pasado. Y, por supuesto, ambas dimensiones se superponen cuando el historiador del pensamiento pretende haber descubierto un importante autor, texto, hecho, idea o momento crucial en el pasado que supondría un genuino punto de origen o cambio de época, pero que por una razón u otra habría pasado inadvertido y permanecido oculto hasta que él logró sacarlo a la luz. ${ }^{24}$

\section{¿Ruptura o continuidad?}

Durante siglos, la narrativa histórica clásica acostumbró a representar el tiempo histórico por medio de un relato que articulaba, como si se tratara de algo continuo, una larga serie de discontinuidades. ${ }^{25}$ Pese a su insistencia en el peculiar espíritu de cada época (Zeitgeist), la revolución cultural historicista de los siglos XVIII y XIX no alteró en esencia este esquema básico de continuidad en la discontinuidad. La(s) filosofía(s) de la historia ofrecia(n) el hilo o marco general en el que se ensartaban todas las historias de épocas y sucesos particulares como las cuentas de un collar. Todas esas historias con minúscula podian integrarse en la omniabarcante Historia con mayúscula. Las periodizaciones al uso recortaban grandes, y no tan grandes, segmentos cronológicos como etapas de una ininterrumpida metamorfosis en la que no habría verdaderos hiatos. El tiempo histórico, aunque escindido en fragmentos discretos, se imaginaba en lo fundamental como un continuum. La historia se pensaba y se escribia como una vasta interconexión de hechos, acciones humanas y procesos solo aparentemente inconexos.

La necesidad de mantener contra viento y marea la identidad amenazada del sujeto -ya sea individual o colectivo- en los graves trances personales o colectivos está probablemente detrás de ese empeño por mostrar alguna clase de permanencia o estabilidad de fondo incluso en medio de desgarradoras rupturas. ${ }^{26}$ ¿Acaso no podemos conjeturar una lógica compensatoria de este tipo en el hecho comprobado de que los revolucionarios de distintas épocas han cubierto, muy a menudo, sus acciones más disruptivas bajo el pudoroso manto de la tradición? ${ }^{27} \mathrm{Al}$ fin y al cabo, puesto que en la existencia de cualquier sujeto suelen alternarse elementos conservadores y renovadores, la opción por enfatizar unos $u$ otros factores, dimensiones o fases está siempre abierta para quien describe retrospectivamente el curso de un largo proceso histórico (o las peripecias biográficas de un personaje). Sin que eso suponga afirmar la arbitrariedad de esas descripciones, me parece innegable que la ponderación del cambio y de la permanencia -e incluso el trazado de la trayectoria- es, en buena medida, 
28

WHITEHEAD, Alfred North. Process and Reality. Nueva York: Free Press, 1979. p. 39. La misma fórmula ha sido aplicada a la obra de Aristóteles: BERNSTEIN, Richard J. Beyond Objectivity and Relativism: Science, Hermeneutics, and Praxis. Oxford: Basil Blackwell, 1983. p. 146.

29

FOUCAULT, Michel. Les mots et les choses. Une archéologie des sciences humaines [1966]. Paris: Gallimard, 1976.

30

KUHN, Thomas S. The Structure of Scientific Revolutions. Chicago: University of Chicago Press, 1962.

31

Cada uno de estos verbos implica una serie de objetivos, métodos y operaciones historiográficas muy diferentes: ANKERSMIT, Frank R. Historia y tropología. Ascenso y caída de la metáfora. México: FCE, 2004, p. 191 ss.

32

En su Introducción metodológica al GG (§ 1.3 y 2.2), Koselleck se refirió a la necesidad de "traducir" o "retraducir" algunos conceptos fundamentales del pasado para de ese modo hacer accesibles sus viejos significados a "nuestra comprensión lingüistica actual" (KOSELLECK, Reinhart. Einleitung. In: GG, Op. Cit., Vol. 1, 1972. p. XIII-XXVII)

33

POCOCK, J. G. A. Time, Institutions and Action: An Essay on Traditions and their Understanding [1968]. In: Political Thought and History. Essays on Theory and Method. Cambridge: CUP, 2009. p. 187-216.

34

INGERFLOM, Claudio. Régime impérial/régime soviétique : ni rupture ni continuité. Espaces Temps, n. 84-86, 2004. p. 226-238. Apoyándose en Gadamer, Ricoeur y Koselleck, Ingerflom impugna las categorias de ruptura y continuidad como herramientas heurísticas adecuadas para analizar el régimen soviético. Véase también en la revista Espaces Temps (n. 82-83, 2003) el dossier Continu/Discontinu. Puissances et impuissances d'un couple. una cuestión de perspectiva. El foco, la escala y la proporción, junto con la retórica utilizada, cuentan mucho a la hora de señalar determinadas continuidades y de concederles preeminencia sobre las rupturas (o al revés).

Pese a su tosquedad, la oposición ruptura/continuidad (dos categorias o formas del pensamiento intuitivas, seguramente insoslayables) parece ejercer asimismo una extraña fascinación sobre los historiadores intelectuales. De hecho, en la historia del pensamiento las posiciones han oscilado entre ambos extremos. Mientras que para algunos autores el foco de la historia intelectual debería ponerse en la novedad, en las rupturas y discontinuidades, otros han sostenido la existencia de una línea evolutiva más o menos continua y sin grandes sobresaltos, o incluso de un zócalo rocoso de cuestiones perennes. Tal vez la expresión más sucinta y lapidaria de esta última posición la encontramos en la manoseada frase de Whitehead según la cual "la tradición filosófica europea" consistiria en esencia en "una serie de notas a pie de página [a la obra] de Platón." ${ }^{28}$

Todos sabemos que en las últimas décadas, entre los practicantes de la historia intelectual, el péndulo se ha desplazado hacia el lado de la falta de continuidad (si bien al mismo tiempo suele reconocerse que en dicha materia no hay cortes netos, ni saltos en el vacío). El primer cuestionamiento de la vieja concepción del pasado como una especie de presente prolongado hacia atrás (y la primera cuña en la visión meramente incrementalista del conocimiento), vino de la mano del historicismo. Sin embargo, como he sugerido en el párrafo anterior, bastantes historiadores del pensamiento, de la filosofía y de la ciencia, siguieron encarando su objeto de estudio presuponiendo una esencial similitud entre las cuestiones planteadas en diferentes épocas.

En cualquier caso, hace casi medio siglo que el énfasis en la discontinuidad de las sucesivas epistemes (por utilizar el término de Foucault) ${ }^{29} \mathrm{O}$ en los cambios de paradigma (para retomar la célebre fórmula de Kuhn) ${ }^{30}$ ha terminado por imponerse en los ambientes académicos de manera abrumadora. La llamada Escuela de Cambridge, en especial los trabajos de Quentin Skinner, han puesto de relieve la discontinuidad entre distintos momentos del pasado (así lo hizo también Koselleck con su teoría del Sattelzeit), y hoy día apenas es posible encontrar historiadores del pensamiento político que no estén dispuestos a admitir de buen grado que la lucha contra el anacronismo semántico entre unas épocas y otras $-y$, con ella, lo que podríamos Ilamar el respeto al "principio de irretroactividad conceptual"- es la mínima cautela exigible a un historiador. Asi las cosas, parece evidente que los marcos intelectivos han cambiado profundamente a lo largo del tiempo, y para entender los mundos pretéritos es preciso recuperar, explicar, comprender, interpretar o representar ${ }^{31}$-táchese lo que no proceda- no solo significados que hoy nos resultan opacos y enigmáticos, sino enteros sistemas de pensamiento y de valoración perdidos, totalmente ajenos a los actuales. ${ }^{32}$

Ahora bien, ¿estamos obligados a elegir entre dos modelos exclusivos y excluyentes, el primero basado en la continuidad y el otro en la ruptura? ¿tertium non datur?

Mi respuesta a esta cuestión es que, gracias a la hermenéutica gadameriana, a la semántica histórica koselleckiana y a algunas reflexiones metodológicas de autores como Skinner o Pocock, ${ }_{1}^{33}$ es perfectamente concebible un género de historia que no nos obligue a escoger un solo plato de ese estrecho menú de tan solo dos opciones. ${ }^{34}$ 
LEMON, Michael C. Continuity, Difference, and Change. In: The Discipline of History and the History of Thought. Londres/Nueva York: Routledge, 1995. p. 54-55. Desde la perspectiva de la narrativa histórico-política clásica, véase, por ejemplo, la configuración de grupos y actores colectivos de los tiempos de la Revolución francesa en la pluma de tres historiadores: A. de Lamartine, J. Michelet y L. Blanc: RIGNEY, Ann. The Rhetoric of Historical Representation. Three Narrative Histories of the French Revolution. Cambridge: CUP, 1990. p. 103-136.

36

En el libro citado al final de la nota anterior, Rigney ha mostrado que algunos historiadores decimonónicos de la Revolución francesa proyectaron sistemáticamente sus anhelos e ideales politicos hacia el pasado: RIGNEY, Ann. The Rhetoric. 0p. Cit. p. 175-176.

37

Esa es una de las razones por las cuales volvemos una y otra vez sobre el pasado y estamos obligados a reescribirlo periódicamente desde los horizontes cambiantes de una serie de presentes constantemente renovados. Véase un reciente (e inteligente) artículo periodístico sobre esta manida cuestión, aplicado a la literatura: CERCAS, Javier. El pasado cambiante. El País Semanal, 23/11/2013. p. 6. Al fin y al cabo, miramos los procesos desde el extremo final de una cadena de acontecimientos e interpretaciones que se hace remontar a un tiempo más o menos remoto: "What links the two ends of the chain", observa Prickett, "is a particular idea of tradition -that in which the new, the truly new, changes all that has gone before to establish, if not a 'new' tradition, then a new version of an existing tradition" (PRICKETT, Stephen. Modernity and the Reinvention of Tradition. Backing into the Future. Cambridge: CUP, 2009. p. 224). En este sentido, "the past [is] altered by the present as much as the present is directed by the past" (ELIOT, T.S. Tradition. Op. Cit.)

38

VEYNE, Paul. Op. Cit. p. 178.

39

PALTI, Elias J. The 'Return of the Subject' as a Historico-Intellectual Problem. History and Theory, n. 43, 2004. p. 79-80. Algo parecido sucede también en las ciencias físico-naturales: "Each scientific novelty did reconfigure everything that had gone before, just as each work of art displaces the meaning of all the artworks that preceded it". (ZAMMITO, John M. Review Article. History/Philosophy/Science: Some Lessons for Philosophy of History. History and Theory, n. 50, 2011. p. 405).

40

Como ha argumentado Wineburg, revestir al pasado con los significados de quien se vuelve hacia un tiempo anterior al suyo es algo completamente natural. Gracias a la educación en el pensamiento histórico, sin embargo, podemos llegar a darnos cuenta -con esfuerzo- de la ingenuidad sobre la que descansa nuestro presentismo y contrarrestar asi el narcisismo epistemológico que aquella actitud conlleva: WINEBURG, Samuel. Historical Thinking and Other Unnatural Acts. Filadelfia: Temple University Press, 2001. p. 3-27.
Ciertamente, todo relato histórico presupone una serie de cambios en la continuidad: para construir una narración debe haber algo -un sujeto, una "identidad"- que persista a través de los cambios. ${ }^{35} \mathrm{Y}$ el efecto literario de ese algo, que permanece y cambia a la vez, puede lograrse narrativamente con relativa facilidad proyectando algunos rasgos de la situación actual hacia el pasado. En el caso de la historia intelectual, es muy frecuente que el historiador reúna unas cuantas notas sémicas percibidas como "esenciales" de un determinado concepto, las proyecte hacia el pasado y presente luego dichas notas como el "núcleo semántico" transtemporal del concepto en cuestión (algo parecido suele suceder cuando las pautas de un cierto tipo de lenguaje o ideología moderna se retrotraen a épocas remotas). ${ }^{36}$

Si bien parece indudable que algunos grandes acontecimientos colectivos tienen la capacidad de "romper el tiempo", esto es, de transformar profundamente el pasado -o, más exactamente, de modificar el sentido y la relevancia otorgada por sus intérpretes a ciertos hechos, ideas o procesos del pasado- ${ }^{37}$ la retroproyección de los conceptos de una época a tiempos anteriores genera una continuidad ficticia $y$, según creo, es una fuente de grandes errores y distorsiones. En efecto, al aparecer un nuevo concepto y al dotarlo de una dilatada prosapia de antecesores, tendemos a atribuir a toda su genealogía un núcleo semántico que se mantendría incólume a lo largo de las generaciones. Este supuesto núcleo invariante sería justamente lo que permitiria reconocer al concepto por encima de las transformaciones sufridas. No es preciso decir que la existencia de tal núcleo invariante es una ilusión retrospectiva. ${ }^{38}$ El resultado, sin embargo, es que, sometido a ese protocolo de (pseudo)historización, el concepto ha cobrado vida propia: ya está listo para ser atribuido con verosimilitud a los agentes que vivieron varias décadas, o varios siglos, antes de su aparición.

Esta clase de anacronismo conceptual, consistente en "la proyección retrospectiva sobre el pasado de las categorias presentes", ha sido llamado

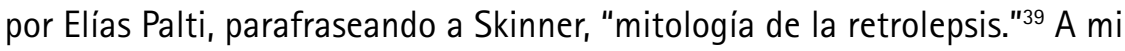
juicio, una de las tareas más espinosas, necesarias y urgentes en historia intelectual es desactivar este endiablado mecanismo que produce sin cesar espejismos conceptuales y trampantojos que resulta extremadamente difícil disipar. ${ }^{40}$

Si no estoy equivocado, las transformaciones, a veces profundas, en la percepción del cambio político-intelectual sufrido por una sociedad en el tiempo, se alimentan en gran medida de esas periódicas transferencias de sentido desde el presente hacia el pasado; al interpretar el pasado a través del nuevo filtro conceptual, la representación y evaluación del mismo se transforma. Surge así un pasado ficticio, ${ }^{41}$ poblado de significados adulterados, postulados extemporáneos, puntos ciegos y realidades imaginarias. Esta retroproyección sistemática de las nuevas conceptualidades emergentes es uno de los mayores obstáculos epistemológicos para nuestra comprensión del pasado, y constituye un dispositivo generador de distorsiones, ilusiones y anacronismos que dificulta sobremanera el trabajo del historiador intelectual.

La historia de los conceptos, que puede ser vista como una propedéutica de la teoria de la historia, ${ }^{42}$ permite comprobar que ciertas palabras del vocabulario político y social que con el tiempo llegarán a ser muy importantes y grávidas de significación cargaron, en sus fases tempranas, contenidos semánticos sumamente livianos y difusos (pensemos, por ejemplo, en 
Por supuesto, todos los pasados son virtuales $-y$, en este sentido, facticios- $y$ solo es posible imaginarlos y comprenderlos desde el presente. Tampoco existen significados ahistóricos, intrinsecos a los textos. Gadamer mostró convincentemente que, teniendo en cuenta al carácter lingüístico e histórico de toda comprensión, debemos renunciar al objetivo imposible de recuperar el sentido genuino, "definitivo" y "verdadero" de los hechos y textos del pasado (como se propusieron aquellos primeros historiadores historicistas, que hoy se nos antojan tan ingenuos): solo la fusión entre el horizonte del intérprete -resultado él mismo de los procesos históricos- y el del tiempo pasado hace posible la tarea hermenéutica (GADAMER, Hans-Georg. Verdad y Método. Op. Cit. p. 376-377, 456-458 y 476-486). Lo que discuto aquí no es eso sin embargo: lo que pretendo mostrar es que muchos historiadores aplican y atribuyen ilegitimamente a los agentes del pasado -o sea, a los muertos, que no pueden protestar por ello- determinados conceptos que para dichos agentes, cuando vivieron, no estaban ni podian estar disponibles.

42

KOSELLECK, Reinhart. Futuro Pasado. Op. Cit. p. 334.

43

LATOUR, Bruno. Nunca fuimos modernos. Ensayo de antropología simétrica. Buenos Aires: Siglo XXI, 2007. p. 114

44

También como un tiempo casi inmóvil ligado a la cotidianeidad, en el que imperaría la rutina y no quedaría ningún resquicio para la novedad: BRAUDEL, Fernand. Las estructuras de lo cotidiano: lo posible y lo imposible. Madrid: Alianza, 1984. Una de las descripciones más impresionantes de la tradición como el tiempo inmóvil, universal e "intrahistórico", de los pueblos la encontramos en el famoso ensayo de Miguel de Unamuno, La tradición eterna, de 1895.

45

Lo tradicional ha solido asociarse a lo popular, y lo moderno a las innovaciones técnicas ajenas a la cultura popular. BENIGNO, Francesco. Las palabras del tiempo. Un ideario para pensar históricamente. Madrid: Cátedra, 2013. p. 136137.

46

GUSFIELD, Joseph R. Tradition and Modernity: Misplaced Polarities in the Study of Social Change. The American Journal of Sociology, Vol. 72, n. 4, 1967. p. 351-362. EISENSTADT, Shmuel Noah. Tradition, Change, and Modernity. Nueva York: Wiley, 1973.

47

HOBSBAWM, Eric y RANGER, Terence (Eds.) The Invention of Tradition. Cambridge: CUP, 1983.

48

Esta aproximación se ha mostrado especialmente fecunda en el estudio de los orígenes culturales de los nacionalismos (especialmente al coincidir su publicación con el no menos influyente libro de ANDERSON, Benedict. Imagined Communities: Reflections on the Origin and Spread of Nationalism. Londres: Verso, 1983). los usos fluctuantes de la vieja palabra Estado, o de la recién acuñada liberalismo, en las primeras décadas del siglo XIX). Y, lo que es más interesante, permite observar cómo ese cuasi-vacío conceptual de su fase incipiente se va llenando poco a poco de contenidos -incluyendo a menudo la forja de una genealogía conceptual por medio de la historización apócrifa de tales términos- hasta cobrar un espesor temporal y una densidad sémica que, con el tiempo, llevará a esos conceptos a ocupar posiciones preeminentes en las constelaciones semánticas de la modernidad política.

\section{Tradición y modernidad}

Desde hace más de medio siglo, las teorias de la modernización nos han acostumbrado a un agudo contraste entre sociedades tradicionales y sociedades modernas. Esta grosera dicotomía, muy utilizada en historia y en ciencias sociales y que con el tiempo ha llegado a consagrarse casi como una evidencia, procede en último término del propio discurso de la modernidad y, en algunos casos, roza la caricatura. "Sociedades tradicionales" y "sociedades modernas" serian dos realidades diametralmente antagónicas, casi sin puntos de contacto entre sí. Como ha observado Latour, "la idea de una repetición idéntica del pasado y la de una ruptura radical con todo el pasado son dos resultados de una misma concepción del tiempo."43 Basándose en esa concepción "moderna" -yo diria, insensatamente moderna- de la temporalidad, historiadores, sociólogos y otros estudiosos forjaron el modelo estilizado de la llamada "sociedad tradicional" como la contrafigura de una no menos idealizada "sociedad moderna" que vendría a sustituir a aquélla a través de una serie de etapas de desarrollo. Pese a esa posibilidad abierta de transitar entre uno y otro estado, dentro de este esquema teórico bipolar, la tradición muy a menudo es presentada como lo que apenas cambia, lo que permanece invariable, lo retardatario, lo residual. ${ }^{44}$ También a veces como una fatalidad a la que quienes tienen la desgracia de vivir en ese tipo de sociedades están amarrados sin poderlo evitar. ${ }^{45}$

Aunque la dicotomía tradición/modernidad como herramienta heurística para el estudio del cambio social, entendido como un proceso lineal, unidireccional, fue ya cuestionada y objetada con buenas razones desde finales de los sesenta ${ }^{46}$ y lo ha seguido siendo hasta nuestros días -estudios postcoloniales, teorias de las múltiples modernidades, etc.-, lo cierto es que sigue estando presente por doquier en la literatura histórica, sociológica y politológica.

Hace tres décadas, Eric Hobsbawm y Terence Ranger publicaron un afamado libro, cuyo título provocador se convertiría enseguida en frase de moda, pero sobre todo en fórmula historiográfica remedada por numerosos historiadores. ${ }^{47}$ Aquella aproximación constructivista a las tradiciones se fijaba casi exclusivamente en lo que aquéllas tenían de inventadas: se trataba de una materia ampliamente manipulable por determinados sectores de las élites interesados en inculcar en la población ciertas normas y valores. La inculcación de dichas normas pasaría por la creación ex profeso de un sentido ficticio de continuidad con el pasado. Este dispositivo de invención, orientado a la emulación y repetición de lo supuestamente transmitido, se activaría con singular eficacia en épocas de grandes cambios y rápidas transformaciones sociales, como lo fueron los inicios de la modernidad. ${ }^{48}$

Después de un periodo de fulgurante éxito historiográfico del enfoque hobsbawmiano, mi impresión es que en los últimos años las críticas empiezan a sobrepujar a las alabanzas. A comienzos de este siglo, la reha- 
PHILLIPS, Mark S. What is Tradition when it is not 'Invented'? A Historiographical Introduction. In: PHILLIPS, Mark S. y SCHOCHET, Gordon (eds.) Questions of Tradition. Toronto: University of Toronto Press, 2004. p. 5. Una breve referencia al concepto de tradición y su transferencia desde el derecho a la religión y de ahi a la cultura en general en: PRICKETT, Stephen. Modernity..., p. 28; véase también ALEXANDER, James. Three Rival Views of Tradition (Arendt, Oakeshott and Maclntyre). Journal of the Philosophy of History, n. 6, p. 21, 2012.

50

POCOCK define la tradición como "a set of present usages and the presumption of their indefinite continuity" (Political Thought and History, p. 202)

51

SIMAY, Philippe. El tiempo de las tradiciones. Antropología e historicidad. In: DELACROIX, Christian; DOSSE, François y GARCÍA, Patrick (eds.) Historicidades. Buenos Aires: Waldhuter, 2010. p. 314; ZHENG, Hangsheng. On Modernity's Changes to 'Tradition': A Sociological Perspective. History and Theory, Vol. 51, n. 4, 2012. p. 106-107. Frente a la idea de la tradición como un legado que uno se limita a recibir de sus antepasados y a trasladar mecánicamente a sus descendientes, se alza una concepción alternativa que pone el acento en el dinamismo activista que implica todo proceso de transmisión. Una cosa es la tradición entendida como un conjunto de contenidos transmitidos que perduran en el tiempo, y otra muy distinta es entenderla como el movimiento complejo de transmisión, transformación y permanente actualización de esos contenidos. En este último sentido, a la tradición solo se accedería con gran esfuerzo y habría de ser renovada constantemente. "Lo que heredaste de tus padres, conquistalo para poseerlo", aconsejaba Goethe. A este respecto observa Maclntyre que las "tradiciones vivas" son aquellas que "progresa[n] gracias a sus disputas y conflictos internos" (MACINTYRE, Alasdair. Tras la virtud. Barcelona: Crítica, 2004, p. 275 y 319). Solo cuando una tradición se esclerotiza y pierde su vigencia se transforma propiamente en pasado (DE CERTEAU, Michel. La Fable mystique. Paris: Gallimard, 1982. p. 41, cit. HARTOG, François. Croire en I'histoire. París: Flammarion, 2013. p. 29)

52

GOMÁ LANZÓN, Javier. La costumbre de vivir. EI País-Babelia, 11/02/2012.

53

SAHLINS, Marshall. The Western Illusion of Human Nature. Chicago: Prickly Paradigm Press LLC, 2008. p. 110.

54

Véase, en esta línea, el reciente libro de MAHONEY, Daniel J. The Conservative Foundations of the Liberal Order: Defending Democracy against its Modern Enemies and Immoderate Friends. Wilmington: ISI Books, 2011.

55

SCHOCHET, Gordon. Tradition as Politics and the Politics of Tradition. In: PHILLIPS, Mark S. y SCHOCHET, Gordon (eds.), Op. Cit. p. 302.

56

SETH, Sanjay. Subject Lessons. The Western Education of Colonial India. Durham/Londres: bilitación del estudio de las tradiciones auténticas, "no inventadas", tiene indudablemente uno de sus hitos en el libro colectivo titulado Questions of Tradition (2004). Uno de sus editores, Mark Phillips, se preguntaba en la Introducción a este volumen precisamente por aquellas otras tradiciones genuinas, y tomaba distancia de la afortunada fórmula de Hobsbawm. ${ }^{49}$ No pocos autores recuerdan ahora que la tradición tiene dos caras: una, ontológica, referida a los contenidos que se transmiten, que enfatiza la continuidad; ${ }^{50}$ la otra, metodológica, realza el cambio y se refiere al proceso de transmisión y a las transformaciones que lo hacen posible. ${ }^{51} \mathrm{Al}$ fin y al cabo vivimos insertos en redes de significados y tradiciones -empezando por la lengua, la tradición por excelencia- que, entre otras cosas, posibilitan el progreso: "quizá los dioses puedan prescindir olímpicamente de las tradiciones"; los seres humanos, no. ${ }^{52}$ Es más: como gustan de subrayar diversos antropólogos, puesto que "las personas se constituyen a sí mismas dentro de ciertas tradiciones culturales", pudiéramos decir -ha sugerido M. Sahlins citando a C. Geertz y a M. Mead- que no existe "naturaleza humana" independiente de la cultura; 0 , dicho de otro modo, que la verdadera "naturaleza humana" es la tradición. ${ }^{53}$

Esta voluntad de rehabilitar la tradición ha podido buscar inspiración y argumentos en la obra de diversos políticos y teóricos liberal-conservadores de los últimos dos siglos, comenzando por Edmund Burke y su célebre alegato contra la Revolución francesa en nombre del prejudice y la prescription. Autores de talante conservador como Alexis de Tocqueville, Raymond Aron, Michael Oakeshott, Alexander Solzhenitsyn, Alasdair Maclntyre y Charles Taylor, cada cual a su modo, han encarecido las virtudes de la tradición, al menos de ciertos aspectos de la misma. ${ }^{54}$ Algunos de estos autores -desde un punto de vista más político o más académico- señalan que, a la postre, es la tradición la que mantiene y fortalece los sistemas de creencias y los vínculos sociales que aseguran un mínimo de estabilidad y cohesión social..$^{55}$ Incluso las disciplinas científicas -historia incluida- y los protocolos a ellas asociados pueden considerarse tradiciones en sentido amplio: todo discurso historiográfico, por ejemplo, se inscribe en un esquema categorial dado y en una serie de prácticas consolidadas a través del tiempo. ${ }^{56}$

Si bien la modernidad ha ofrecido diversos sucedáneos para la tradición -la opinión pública y las ideologias serian probablemente los candidatos más plausibles para ocupar en las sociedades modernas el lugar de la tradición (pero enseguida veremos que no son incompatibles) $-{ }^{57}$ si entendemos la tradición lato sensu como la transmisión intergeneracional de elementos culturales (la misma noción de tradición ha conocido una larga serie histórica de reconceptualizaciones, pasando a grandes rasgos de una gama de significados religiosos a otra más secular), es obvio que resulta inconcebible cualquier forma compleja de convivencia humana, antigua o moderna, sin tradición. La llustración y la propia modernidad constituye un ejemplo de "tradición de la razón", y las ideologias y doctrinas políticas modernas pueden verse asimismo como formas de tradición. ${ }^{58}$

Jörn Rüsen ha sugerido recientemente que si nos tomásemos en serio la presunción académica de que toda tradición es, à la Hobsbawm, una construcción interesada del pasado al servicio de intereses más o menos espurios del presente, ello supondría negar la función cultural de la tradición. Entender la tradición como algo inventado equivale, en el fondo, a rechazar su capacidad para infundir en el espíritu humano un cierto orden 
Duke University, 2007. p. 97-98. El concepto de tradición -que desde esta perspectiva casi no se distingue del de práctica- es lo bastante elástico para que pueda ser aplicado, en este caso, bien a la historia como disciplina, bien a una sub-disciplina como la historia del pensamiento político, o incluso a cualquiera de sus ramas, esto es, al conjunto de aquellos estudiosos que cultivan un enfoque particular para el estudio histórico del pensamiento.

57

SCHOCHET, Gordon. Op. Cit. p. 296. PHILLIPS, Mark S. Op. Cit. p. 17.

58

PHILLIPS, Mark S. Op. Cit. p. 7.

59

RÜSEN, Jörn. Op. Cit. p. 49.

60

Idem. p. 59. GADAMER, Hans-Georg. Op. Cit. p. 337 y ss. Uno de los aspectos de la reflexividad moderna sobre las tradiciones es la necesidad de justificar ideológicamente su validez (GEERTZ, Clifford. La interpretación de las culturas [1973]. Barcelona: Gedisa, 2000. p. 190-192).

61

En relación al arte escribe Félix de Azúa: "Desde el Renacimiento, toda producción artística y toda empresa intelectual de cierto empaque debe inventar su propio pasado para encajarse en una tradición u otra" (AZÚA, Félix de. Diccionario de las artes. Barcelona: Planeta, 1995, p. 278).

62

KOSELLECK, Reinhart. historia/Historia, Op. Cit. p. 126. En relación con esta asignación de (nuevos) pasados a los (nuevos) futuros y la posición de Hannah Arendt al respecto, véanse los comentarios de HARTOG, François. Op. Cit. p. 251-252.

63

MEINECKE, Friedrich. Op. Cit. p. 79. KOSELLECK, Reinhart. historia/Historia, 0p. Cit. p. 115-116, 126; _ Futuro pasado, 0p. Cit. p. 180-183. SMITH, Leonard S. Op. Cit. p. 51-52 y 119. PRICKETT, Stephen. Op. Cit. p. 12. dado de antemano.$^{59}$ Dicho de otra manera, lo que Rüsen plantea es que si todas las tradiciones fuesen "inventadas" y no hubiera ninguna tradición "verdadera", la vida humana carecería de marcos relativamente estables para su desenvolvimiento.

Este autor distingue tres tipos de tradición: vigente o funcional (functioning tradition), reflexiva (reflective tradition) y latente (dormant tradition). La primera -quizás la acepción más común de la palabra- proporciona certezas y se mantiene activa y prestigiada, reforzando ciertas creencias socialmente aceptadas acerca del origen y la continuidad de algunos rasgos socioculturales a largo plazo. La segunda, la reflexiva, solo se manifiesta cuando la tradición empieza a tematizarse (como estamos haciendo en este trabajo) y su papel en la sociedad pasa a ser objeto de debate. La tercera, a la que califica de "durmiente", es una forma de tradición invisible, silenciosa, pero no por ello menos eficaz a la hora de conformar ciertos elementos inconscientes de la cultura (probablemente su sentido no se aleja demasiado de lo que Gadamer llama prejuicio [praeiudicium], entendido como condición de la comprensión). ${ }^{60}$

Ex innovatio traditio: Las tradiciones (s)electivas y plurales de los modernos Mi propuesta es agregar una modalidad más a las tres planteadas por Rüsen. Se trataría de un tipo de tradiciones -en plural- peculiarmente modernas que tendrian más de un punto en común con las "tradiciones inventadas" de Hobsbawm, pero también considerables diferencias. Podríamos llamarlas tradiciones electivas y se situarian a medio camino entre los dos primeros tipos de la clasificación rüseniana (puesto que serian fun-

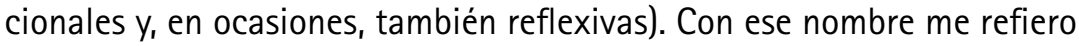
especialmente a aquellas tradiciones que los constructores de las grandes ideologías contemporáneas atribuyen a sus propios movimientos sociales 0 políticos, que aparecen asi dotados de una prosapia histórica más o menos ilustre. Enseguida trataremos de especificar un poco más en qué consisten las tradiciones electivas (o selectivas, si se quiere). Pero antes tal vez merezca la pena disipar un malentendido en torno a la interacción entre modernidad y tradición.

El hábito de considerar tradición y modernidad como términos antagónicos ha ocultado el hecho paradójico de que es precisamente en la era moderna cuando las tradiciones han proliferado de manera inusitada, en particular en los dominios del pensamiento y las artes. ${ }^{61}$ En efecto, en el nuevo tiempo inherentemente perspectivista de la modernidad, observó Koselleck, "con cada nuevo futuro surgen nuevos pasados." ${ }^{62} \mathrm{~A}$ mediados del siglo XVIII, mientras Chladenius advertía que el observador siempre ve las cosas desde algún lugar determinado (Sehepunckt) y por tanto "narrar una cosa sin ningún punto de vista [...] es imposible", Voltaire, fuertemente comprometido con la propagación de las Luces, constataba que las disputas ideológicas - por ejemplo, entre philosophes y antiphilosophes- eran inseparables de los combates por la historia. Como hizo notar Meinecke, desde entonces "la lucha en torno de la significación del pasado histórico acompañó [...] a todas las luchas en torno a la estructuración del porvenir."63

El resultado de esa prolongada pugna perspectivista por el sentido de la historia ha sido una plétora de tradiciones alternativas. "Ninguna época de la humanidad", asevera Azúa, "había producido una tan notable cantidad de pasados simultáneos". La invención de tradiciones en el mundo moderno, añade este autor en su Diccionario de las artes, ha llegado a ser 
64

AZÚA, Félix de. Op. Cit. p. 279.

65

"The idea of tradition has become an essential ingredient in modernity" (PRICKETT, Stephen, Op. Cit. p. 13).

66

KOSELLECK, Reinhart. Innovaciones conceptuales del lenguaje de la llustración. In: Historias de conceptos. Estudios sobre semántica y pragmática del lenguaje político y social. Madrid Trotta, 2012. p. 199-224.

67

Incluso sobre el presente del historiador, pues, como observa Rüsen respecto de la historia (y podría predicarse también de la tradición) "before we start to construct history, history has already constructed us" (DA MATA, Sérgio y LOPES DE ARAUJO, Valdei. Jörn RÜSEN: Theory of History as Aufklärung. História da Historiografia, Ouro Preto, n. 11, 2013. p. 344).

68

LANGEWIESCHE, Dieter. Op. Cit. p. 46 y 52.

"What constitutes a tradition", señala por su parte Macintyre, "is a conflict of interpretation of that tradition, a conflict which itself has a history of rival interpretations". MACINTYRE, Alisdair. Epistemological Crise, 0p. Cit. p. 460.

70

Vide supra, nota 37. Pensemos en las tradiciones rivales en que aparece dividido el cristianismo: todas las iglesias y sectas cristianas se basan en interpretaciones divergentes de un mismo corpus de Escrituras sagradas, principalmente en el Nuevo Testamento. Algo parecido puede afirmarse de los grupos musulmanes (sunies y chiies, principalmente) con respecto a los textos coránicos.

71

POUILLON, Jean. Tradition: transmission ou reconstruction? In: Fétiches sans fétichisme. París: Maspero, 1975. p. 160, cit. por SIMAY, Philippe. Op. Cit. p. 316-317. "La modernidad [tiende] a seleccionar un tipo de pasados que se ajusten [...] a su sensación de movimiento y cambio" (ZERMEÑO PADILLA, Guillermo. La cultura moderna de la historia. Una aproximación teórica e historiográfica. México: El Colegio de México, 2002, p. 68). Aunque en cierta medida son siempre los "sucesores" quienes eligen a sus "predecesores", abrazando determinados elementos del pasado y desdeñando otros (TUSHNET, Mark. The Concept of Tradition in Constitutional Historiography. William and Mary Law Review, Vol. 29, n. 1, 1987, p. 94), a mi juicio esta pauta de transmisión cultural ha cobrado mucha más relevancia en los últimos siglos.

72

BENIGNO, Francesco. 0p. Cit. p. 132-133. tan sistemática y acelerada que los dos términos, invención y tradición casi se han convertido en sinónimos. ${ }^{64}$

Los comentarios de Koselleck, Meinecke y Azúa sobre este asunto apuntan a la misma conclusión, que no es otra que ver la modernidad como un venero inagotable de tradiciones. ${ }^{65}$ La revolución, que se presenta como una ruptura con la tradición es, de hecho, -como toda época de crisis existencial- un fecundo laboratorio de mitos y tradiciones. Lo característico del paso a la modernidad no sería tanto que la innovación desplace en bloque a la tradición cuanto que la voluntad de innovación sistemática, ${ }_{1}^{66}$ visible en casi todos los terrenos, alcance parcialmente incluso al ámbito de las tradiciones. Aunque lo que la tradición tiene de "pasado vivo", involuntario, siga gravitando y actuando tácitamente sobre el presente, ${ }^{67}$ en la llamada sociedad moderna cobran cada vez más peso otro tipo de tradiciones voluntaristas, plurales, a la carta: las tradiciones electivas.

En la práctica, los modernos no dudan en rebuscar en el abigarrado depósito de la historia aquellos elementos más funcionales para sus proyectos. Tal es el caso, de manera paradigmática, de los nacionalismos del siglo XIX: "Todas las naciones modernas", ha subrayado Langewiesche, "se dotan, mediante sus mitos fundacionales, de una tradición histórica que identifica lo nuevo como regreso o culminación de lo antiguo." ${ }^{68}$ Distintos movimientos sociales y políticos proceden de manera similar a autoasignarse tradiciones históricas que muchas veces comparten determinados referentes con otras corrientes y grupos; a menudo, distintos agentes compiten por consagrar sus propias interpretaciones alternativas de una misma tradición particular ${ }^{69}$ (incluyendo, por cierto, las "tradiciones revolucionarias", por usar un oxímoron reconocible). Y esas tradiciones, al mirar hacia el origen desde el final de una larga cadena de unidades que se presuponen necesariamente eslabonadas, cierran la puerta a la contingencia para adoptar un perfil inequívocamente teleológico (más adelante me detendré brevemente en la "aporia de los orígenes" en historia intelectual). ${ }^{70}$ Podemos entender pues las tradiciones electivas de los modernos (a las que podria convenir el lema ex innovatio traditio), más que como una herencia recibida de las generaciones anteriores, como un legado histórico imaginado y elaborado por el propio legatario. De entre todos los pasados posibles, cada actor colectivo selecciona de acuerdo con sus preferencias aquellos hechos, autores o episodios históricos en los que de algún modo se reconoce: aquellos que mejor se adaptan a sus necesidades de legitimación y a sus expectativas de futuro. La tradición pasaría a ser vista como "una filiación invertida: el hijo, aquí, engendra a su propio padre, iy por eso puede darse varios! [...]. Escogemos aquello por lo cual nos declaramos determinados, nos presentamos como los continuadores de aquellos que hemos convertido en nuestros predecesores." ${ }^{71}$ Más que pensarse como una herencia del pasado, desde esta perspectiva la tradición "debe plantearse como una interpretación del tiempo transcurrido, un punto de vista que los hombres del presente desarrollan sobre lo que les ha precedido."72

Mientras que la "tradición tradicional" (si se me permite el truismo) tiende a ser entendida de manera monista y su vector principal se dirige del pasado al presente, este nuevo género de "modernas tradiciones" -plurales, abiertas y fuertemente ideologizadas- invierte el sentido de la flecha del tiempo. La orientación general "futurocéntrica" del mundo moderno se extiende en este caso también a la tradición, que es enrolada a la fuerza en los combates por el porvenir. Las tradiciones electivas son perfiladas 
73

La cultura de ciertos sectores radicalizados del republicanismo español de los siglos XIX y XX, sobre las huellas del jacobinismo, se mostró particularmente tajante a este respecto. "La República no tiene tradición; no necesita tradición. Es una idea moderna", leemos en un periódico republicano de Bilbao (FERNÁNDEZ DíAZ, José. Sobre la unidad nacional. El Liberal, 08/05/1932). Conviene añadir de inmediato que numerosos intelectuales y líderes del republicanismo -N. Alcalá Zamora, M. Azaña, J. Ortega y Gasset, F. Fernando de los Riossaludaron la proclamación de la II República en 1931 como "la reanudación de una gran tradición española, de una tradición liberal, de una tradición popular" (discurso de Manuel AZAÑA, 28-III-1932; cit. en FERNÁNDEZ SEBASTIÁN, Javier y FUENTES, Juan Francisco, (Dir.) Diccionario político y social del siglo XIX español. Madrid: Alianza, 2002, p. 428). Vide infra, en nota 77, una declaración de Manuel Azaña bien explícita al respecto.

74

RODGERS, Daniel T. The Traditions of Liberalism. In: PHILLIPS, Mark S. y SCHOCHET, Gordon (eds.). Op. Cit. p. 202-232. Véase para el caso del liberalismo español: FERNÁNDEZ SEBASTIÁN, Javier. Liberalismo en España, 1810-1850. La construcción de un concepto y la forja de una identidad politica. In: (ed.) La aurora de la libertad. Los primeros liberalismos en el mundo iberoamericano. Madrid: Marcial Pons Historia, 2012. p. 280 y ss.

75

MELLON, Stanley. The Political Uses of History. A Study of Historians in the French Restoration. Stanford: Stanford University Press, 1958.

76

DE BONALD, Louis. Observations sur l'ouvrage de Madame la baronne de Staël (1818). In: CEuvres, V, p. 400-401, cit. en MELLON, Stanley. Op. Cit. p. 61.

77

ALCALÁ GALIANO, Antonio. Lecciones de Derecho Politico [1838]. Madrid: CEC, 1984, p. 22. Casi un siglo más tarde, el presidente del Gobierno y futuro presidente de la II República española, Manuel Azaña, enfatiza en una alocución pronunciada en 1932 que "la vida espiritual del hombre está gobernada por la tradición, y cuando parece que la combate, la continúa" (AZAÑA, Manuel. Discursos políticos. Ed. de Santos Juliá. Barcelona: Crítica, 2004. p. 172)

78

MARX, Karl. El 18 Brumario de Luis Bonaparte. Barcelona: Ariel, 1968, p. 11.

79

Idem. p. 11-15. para dotar retrospectivamente a tal o cual concepto, a tal o cual grupo o movimiento, a tal o cual ideología, de un pasado ad hoc especialmente diseñado para dar verosimilitud a las expectativas de futuro que parecen desprenderse naturalmente de ese pasado. De manera que en el mundo moderno no solo los conservadores y tradicionalistas disponen de tradiciones propias: pese a las trasnochadas protestas de algunos progresistas de haber roto radicalmente con el pasado ${ }^{73}$ también los liberales, republicanos, demócratas, socialistas, anarquistas o comunistas tienen las suyas, y de esas veneradas tradiciones extraen fuerzas para seguir avanzando y para dar sentido a sus proyectos. ${ }^{74}$

En la Europa de comienzos del siglo XIX es posible seguir el cambio de actitud de los primeros liberales con respecto a la tradición, paralelamente al avance de la nueva mentalidad romántica. Mientras los revolucionarios franceses, instalados la mayoría de ellos todavía en la visión geométrica de la política típica de las Luces, pretendieron romper con la tradición en nombre de la razón, los liberales de la Restauración se interesan por la historia y dirigen una mirada mucho más indulgente hacia el pasado. ${ }^{75} \mathrm{Mme}$. de Staël quien, como es sabido, empezaba a sostener por entonces que la libertad es antigua y el despotismo, moderno, fue replicada airadamente desde las filas del tradicionalismo. Así, en la Francia de 1818 el vizconde de Bonald arremete contra tal pretensión acusando a los "innovadores políticos" de disfrazar sus radicales novedades bajo el manto de la tradición, como habian hecho en el pasado los promotores de herejías, "saqueando los [textos antiguos de los] siglos más remotos en busca de algún precedente para sus doctrinas."76

En España, si bien la corriente principal del liberalismo buscó desde el principio lejanos precedentes históricos -en la Edad Media y en la rebelión de los comuneros (1521)- para su lucha por la libertad, podemos observar en varios teóricos de los años treinta y cuarenta una defensa activa del valor de la tradición. En el Ateneo de Madrid, Alcalá Galiano critica la voluntad de la "escuela racionalista" de hacer tabla rasa del pasado: "así como algo del ser de nuestros mayores está en nosotros, diciéndose no sin razón que su sangre circula por nuestras venas, así está en nuestra mente y corre por nosotros todos algo de las ideas de nuestros antepasados, siendo vano empeño querer desprendernos de ello absolutamente." ${ }^{177}$

No era esa, desde luego, la opinión de los grupos revolucionarios y radicales al respecto. En un fragmento bien conocido, Karl Marx utilizó una imagen muy distinta de la de Galiano para referirse a la tradición; en lugar de la "sangre que circula por nuestras venas", Marx utilizó la metáfora de la pesadilla que nos atenaza: "La tradición de todas las generaciones muertas oprime como una pesadilla el cerebro de los vivos." ${ }^{178} Y$, a renglón seguido, les aconsejó a los revolucionarios de su tiempo despertar de una vez de esa pesadilla: dejar en paz a los muertos e inspirarse en el porvenir, en lugar de en el pasado, como habian hecho los protagonistas de las revoluciones inglesa y francesa, cuando se veían reflejados a sí mismos y a sus vicisitudes en ciertos episodios del Antiguo Testamento o de la República romana, respectivamente. $^{79}$

Las palabras de Alcalá Galiano que hemos reproducido más arriba ilustran suficientemente el hecho de que la tradición, en su sentido más común, siguió siendo pese a todo muy apreciada por destacados autores liberales. Ello no fue óbice para que la forja de tradiciones selectivas que acompañó a la nueva oleada de modernidad política siguiera su curso. 
CABRERA, Miguel Ángel. Postsocial History. An Introduction. Lenham: Lexington Books, 2005. p. 37-38.

81

Así ocurrió con el liberalismo español surgido en 1810. La obra de Martínez Marina (en particular su Teoría de las Cortes, 1813) testimonia la creación casi inmediata de un pasado medieval para muchos de los conceptos -representación soberanía nacional, opinión pública, libertadesque cobraron entonces gran importancia en el discurso político de aquellos primeros liberales. No solo se generó así un pasado a la medida del futuro diseñado para las incipientes instituciones liberales, sino que, al aplicar retrospectivamente estos conceptos, los fenómenos sociales y políticos asociados parecian cobrar vida propia en épocas anteriores. GONZÁLEZ MANSO, Ana Isabel. Historicismo, Edad Media y conceptos políticos en el primer liberalismo español (1808-1845). 2013. Tesis. (Doctorado), Universidad del País Vasco, Bilbao, 2013.

82

Así, apenas lanzado el concepto de opinión pública en el debate político español, Juan Antonio Llorente lo proyecta a tiempos lejanos en su obra. LLORENTE, Juan Antonio. Memoria histórica sobre cuál ha sido la opinión nacional de España acerca del tribunal de la Inquisición. Madrid: Sancha, 1812

83

Eso es también aplicable a las "revoluciones científicas", mucho menos cataclísmicas de lo que suele suponerse. No se trata solo de que haya permanentemente cambios, evoluciones y ajustes graduales dentro de cada paradigma. Tampoco los cambios de paradigma que Kuhn propuso para la ciencia suponen -en las ciencias biológicas, por ejemplo- la total sustitución de los conceptos existentes en un plazo muy breve sino más bien la coexistencia del viejo sistema conceptual con el nuevo y la competencia mutua entre ambos sistemas durante largo tiempo (MAYR, E. This is Biology: The Science of the Living World. Cambridge, Mass.: The Belknap Press, 1997. p. 98-99).

84

GADAMER, Hans-Georg. Op. Cit. p. 344 y ss.
Aunque es indudable que cualquier nuevo concepto o discurso surge de la reconfiguración de elementos semánticos preexistentes, ${ }_{1}^{80}$ no lo es menos que -como he tratado de explicar en un epígrafe anterior- la acuñación de nuevas nociones y con ellas, el surgimiento de nuevas instituciones, desencadena una dinámica de búsqueda y selección de antecedentes que genera muy pronto la ilusión de que tal concepto o institución venía ya existiendo o actuando in fieri desde épocas remotas. ${ }^{81}$ Lo que en un momento fugaz fue visto como innovación es rápidamente re-descrito como un "descubrimiento", dando así a entender que en realidad el fenómeno sociopolítico recién conceptualizado estaba ya ahí con anterioridad. ${ }^{82}$

En el dominio de la historia intelectual, las historias heroicas de la gran marcha de la libertad, de los derechos o de la emancipación humana (todavia demasiado tributarias de las interpretaciones whigs y protestantes, hegelianas o marxistas de la historia) despliegan una retórica convencional -que hemos heredado de las filosofías de la historia de la llustración- en que las fuerzas de la innovación luchan denodadamente contra las resistencias oscurantistas de la tradición. Mientras que en ciertos casos, la tradición es vista como un lastre que dificulta el avance de la sociedad hacia metas de mayor perfeccionamiento y progreso, como una resistencia que es preciso vencer; en el límite, en este tipo de aproximación la tradición misma -algunos de sus contenidos al menos- se revela finalmente como una estratagema, como una impostura que el historiador ilustrado debiera esforzarse por desvelar, criticar y desmitificar.

Frente a esa caricaturesca contraposición de tradición e innovación, con sus contrastes maniqueos entre un mundo estático, rutinario y retardatario y otro dinámico, original e innovador, visión que todavía se mantiene por inercia en algunos sectores de la historiografía, hoy en la historia del pensamiento dominan aproximaciones bastante más sofisticadas, retóricas más ricas en matices, que niegan la validez de una antinomia que se complace en reproducir una y otra vez la misma imagen en blanco y negro. Hoy es frecuente subrayar la dificultad de separar en la práctica ambas categorias, y señalar que muchos procesos históricos se caracterizan precisamente por distintos grados de hibridación entre elementos viejos y nuevos, de modo que la transmisión cultural se muestra perfectamente compatible con la renovación y el resurgimiento de lo nuevo. Desde la historia de la ciencia hasta la hermenéutica filosófica -apoyándose en los trabajos clásicos de Gadamer y de Kuhn, entre otros-, son varias las líneas metodológicas que enfatizan de diversas maneras que sin un fondo de permanencia y transmisión de los saberes no es posible la innovación y que la invención misma bebe muy a menudo en las fuentes de la tradición: $E x$ traditio innovatio. ${ }^{83}$

La hermenéutica filosófica de Gadamer, al insistir sobre la lingüisticidad e historicidad de toda comprensión, ha mostrado que, puesto que la tradición está imbuida en el lenguaje (y viceversa), la comprensión sería imposible sin ella. De hecho, el círculo hermenéutico presupone una interacción entre intérprete y tradición, entendida esta como ineludible infraestructura del conocimiento. ${ }^{84}$

En este punto, las reflexiones metodológicas de la historia intelectual, ya se trate de los estratos del tiempo y las estructuras de repetición 
KOSELLECK, Reinhart. Estructuras de repetición en el lenguaje y en la historia. Revista de Estudios Políticos, n. 134, 2006, p. 17-34

86

SKINNER, Quentin. Los fundamentos del pensamiento político moderno. México: FCE, 1985, Vol. 1, p. 10-11. KOSELLECK, Reinhart. Sozialgeschichte und Begriffsgeschichte. In SCHIEDER, W. y SELLIN, V. (eds.): Sozialgeschichte in Deutschland: Entwicklungen und Perspektiven im internationalen Zusammenhang. Gotinga: Vandenhoeck \&t Ruprecht, 1987, Vol. 2. p. 102 (cit. PALTI, Elias José. Ideas, conceptos, metáforas. La tradición alemana de historia intelectual y el complejo entramado del lenguaje. In: FERNÁNDEZ SEBASTIÁN, Javier y CAPELLÁN, Gonzalo, (eds.) Lenguaje, tiempo y modernidad. Ensayos de historia conceptual. Santiago de Chile: Globo, 2011. p. 224-225).

87

LOTMAN, Yuri M. Estructura del texto artístico. Madrid: Istmo, 1982, p. 35. Sobre el entrelazamiento de tradición e innovación, incluso en las vanguardias, véase PAMPARACUATRO MARTÍN, Javier. Signo y valor. Estudio sobre la estética semiótica del hecho literario. Bilbao: Universidad del País Vasco, 2012. p. 334-337. Sobre la función de la tradición en la modernidad véase ZERMEÑO PADILLA, Guillermo. Op. Cit. p. 68 y ss.

88

PHILLIPS, Mark S. Op. Cit. p. 24-25.

89

POCOCK, J.G.A. Op. Cit. p. XI-XIV, 72.
(Koselleck) ${ }_{1}^{85}$ o de los lenguajes políticos disponibles (Pocock y Skinner), concuerdan sustancialmente en que el lenguaje no es un mero instrumento a la entera disposición del individuo, sino una red intersubjetiva transgeneracional de la comunidad de hablantes (o, más en particular, si hablamos de un lenguaje entre otros, en el sentido de Pocock, de los usuarios de una determinada tradición de discurso). De ahí que, incluso cuando se trata de innovar de manera radical, como mostró Skinner, es obligado servirse del lenguaje disponible, esto es, recurrir de un modo u otro al depósito de la tradición. ${ }^{86}$ "Toda obra innovadora", escribe Lotman, "está construida con elementos tradicionales. Si el texto no mantiene el recuerdo de la estructura tradicional, deja de percibirse su carácter innovador." ${ }^{87}$

Así pues, tradición e innovación, lejos de ser términos incompatibles, se entrelazan e implican mutuamente: los actores, incluso los más radicales, no pueden dejar de volver continuamente la mirada hacia atrás para fundar sus anhelos y aspiraciones. Mucho antes de que los modernos historiadores de la cultura proclamasen que ningún cambio cultural es absoluto y que los significados ni surgen en el vacío ni se aniquilan por completo en un tiempo corto, Lucrecio dejó escrito en el siglo I a. C. que, pues "de la nada, nada puede hacerse", "ninguna cosa nace de la nada" (De rerum natura, v. 211 y 219). Como se ve tampoco ésta es, en rigor, una idea nueva.

La teorización kuhniana sobre la historia de la ciencia muestra también que la visión "continuista", que pone el acento en la fuerza de la tradición, es mucho más compatible de lo que parece a primera vista con el énfasis en la escansión y en la innovación radical que, de cuando en cuando, provocaria un "cambio de paradigma." ${ }^{88}$ En este sentido, The Structure of Scientific Revolutions (1962) contribuyó a mitigar la (falsa) oposición frontal entre tradición e innovación, en la medida en que mostró los mecanismos en virtud de los cuales una "tradición disciplinar" o paradigma, se ve desafiado hasta el punto de ser sustituido por una tradición alternativa, o paradigma emergente. Así, Kuhn logró combinar de un modo relativamente original y sofisticado los vocabularios de la tradición -mejor, de una pluralidad de tradiciones- y los de la innovación. No es casual que un especialista como J. G. A. Pocock se interesara desde principios de los setenta en aplicar el modelo teórico kuhniano al estudio de la historia intelectual, usando como si fuesen intercambiables los términos "paradigma", "tradición", "discurso" y "lenguaje político" -si bien fue esta última fórmula la que finalmente hizo fortuna- ${ }^{89}$

\section{La nueva historia intelectual y sus metáforas}

Inspirada en las filosofías de la historia de la modernidad en el momento de su triunfo, la dicotomía tradición/modernidad no es inocente ni exterior al estado de cosas que aspira a aprehender conceptualmente. Nos hallamos, por el contrario, ante dos contraconceptos asimétricos inequívocamente dependientes del "paradigma de la modernidad", asociados al nuevo "régimen de historicidad" (Hartog) surgido en Occidente a finales del siglo XVIII y comienzos del XIX. Una engañosa dicotomía que, como he tratado de mostrar en estas páginas, puede conducir al historiador a un callejón sin salida si se la toma demasiado en serio.

Pues bien, algunas reflexiones y herramientas heurísticas de la historia conceptual, en especial la teoria de los tiempos históricos de Koselleck, resultan de gran ayuda para cuestionar esa aporía y todo el séquito de estériles contraposiciones que la acompañan (ruptura/continuidad y otras 
JORDHEIM, Helge. Against Periodization: Koselleck's Theory of Multiple Temporalities. History and Theory, n. 51, p. 151-171, 2012.

91

KOSELLECK, Reinhart. Zeitschichten. Francfort: Suhrkamp, 2000.

92

WITTGENSTEIN, Ludwig. Investigaciones filosóficas. Barcelona: Critica, 1988. p. 87-89. Michael Freeden ha observado la pertinencia de esta analogía para ilustrar cómo la tradición constituye una continuidad que sin embargo cambia a lo largo del tiempo (FREEDEN, Michael. Ideology. A Very Short Introduction. Oxford: OUP, 2003. p. 44).

93

Véase otra penetrante metáfora -en este caso procedente de la dinámica de fluidos- que permite apreciar el desarrollo e interacción de los conceptos en el tiempo, en SENELLART, Michel. Les arts de gouverner. Du regimen médiéval au concept de gouvernement. Paris: Seuil, 1995. p. 46. similares). La semántica koselleckiana de los tiempos históricos contempla una serie de "estratos" de significado, procedentes de diversas épocas y moviéndose a distintas velocidades, operando sobre la lengua en un momento dado; la compleja relación entre sincronía y diacronía permite entonces concebir la coincidencia en el tiempo de planos semánticos simultáneos, pero no contemporáneos. Esta teoría parece abrir una alternativa a la manida -y un tanto mecánica- visión de la historia como una sucesión de periodos separados por claras cesuras. ${ }^{90}$

Y, como sugeríamos en la primera parte de este trabajo, cuando se trata de pensar el cambio, los instrumentos utilizados para captarlo importan sobremanera. No es lo mismo utilizar como retícula de lectura la burda dicotomía ruptura/continuidad que la mucho más sofisticada temporalidad hojaldrada de los campos de experiencia, los horizontes de expectativa y los estratos del tiempo koselleckianos. El recurso a estas metáforas heuristicas hace posible comprender que, generalmente, lo que cambia y lo que pervive coexisten de modo no excluyente. ${ }^{91}$

Tal parece, en efecto, que solo por vía figurada es posible vislumbrar ciertas lógicas y estructuras subyacentes a la dinámica de la tradición.

No por casualidad algunas célebres metáforas wittgensteinianas -"aire de familia", "fotografías borrosas", "juegos de lenguaje", etc.- están entre los recursos intelectuales más sutiles a nuestra disposición cuando tratamos de entender qué es un concepto o cómo funciona el lenguaje. La compleja naturaleza de la tradición, especialmente en lo que se refiere a su inherente dialéctica entre continuidad (ilusoria) y discontinuidad, puede aclararse en parte mediante otra metáfora de Wittgenstein; tratando de explicar cómo agrupamos diferentes ítems en un conjunto al que llamamos "números", el filósofo vienés establece una analogía con la práctica textil del hilado: "como cuando al hilar trenzamos una hebra hilo a hilo. Y la robustez de la hebra no reside en que una fibra cualquiera recorra toda su longitud, sino en que se superpongan muchas fibras." ${ }^{92}$ Así como lo que recorre la hebra entera no es ninguna fibra en concreto, sino la continua superposición de fibras, una tradición intelectual no se refiere a ningún contenido imperecedero, sino más bien a una sucesión de fragmentos apenas "discontinuamente" superpuestos, pequeñas porciones entrelazadas (mechones o copos de lana, algodón u otra materia textil que antes de trenzarse eran independientes entre sí, y lo siguen siendo en cierta medida si los desenredamos) que producen la ilusión de continuidad. (De hecho, cuando esa continuidad se quiebra, o se recupera, decimos que "se ha roto, o que se ha reanudado, el hilo de la tradición").

Si bien esta analogía por segmentos es preferible a la de las cuentas enhebradas en un collar (o de los vagones de un tren), tampoco me parece enteramente satisfactoria, puesto que la palabra hilo tiene connotaciones demasiado ligadas a la continuación o persistencia de algo, y por tanto invita a pensar en términos de unicidad y unidireccionalidad..$^{93}$ Para nuestro uso particular como historiadores, quizá podríamos corregir y matizar esa analogía pensando más bien en varios hilos entrelazados y anudados de un modo aparentemente azaroso, a la manera de los quipus incaicos, para subrayar la contingencia, apertura y pluralidad de las tradiciones intelectuales.

\section{La quimera del origen}

Me gustaria añadir una última reflexión critica acerca del problema de los orígenes en historia de los conceptos y discursos. Cuando en un apartado 
94

Un ejemplo señero de este género es el ensayo de Weber sobre La ética protestante y el espiritu del capitalismo (1905), pero hay decenas de libros mucho menos brillantes y conocidos que ilustrarian mejor el nivel medio del tipo de obras al que aqui aludimos. Vide supra, nota 24.

95

CHARTIER, Roger. La chimère de I'origine. Foucault, les Lumières et la Révolution française. In: Au bord de la falaise. Paris: Albin Michel, 1998. p. 132-160. FOUCAULT, Michel. L'Archéologie du savoir. Paris: Gallimard. 1969. Nietzsche, la généalogie, I'histoire" (1971). In: Dits et écrits. Paris: Gallimard, 1994, Vol. 2. p. 136-156. Véase también WILSON, Timothy H. Foucault, Genealogy, History. Philosophy Today, Vol. 39, n. 2, 1995. p. 157-170.

96

CHARTIER, Roger. Op. Cit. p. 134.

97

BLOCH, Marc. Introducción a la historia. México: FCE, 1952. p. 27-32. anterior me referi a la retórica de la innovación en historia intelectual, mencioné que con cierta frecuencia en nuestra disciplina se publican obras cuyos autores pretenden haber descubierto algún hecho, causa oculta o momento crucial en el pasado que habría supuesto un verdadero punto de inflexión, activando un proceso de cambios de enorme trascendencia en el futuro (lo más habitual es que estas narrativas se refieran al origen oscuro de algún rasgo característico de la modernidad). ${ }^{94}$ Gran parte de estas obras no pasan de ser versiones más o menos inspiradas, o provocadoras, de eso que Roger Chartier llamó hace años, siguiendo a Foucault, "la quimera del origen." 95

En este sentido, un corolario positivo del famoso descrédito de los "grandes relatos" ha sido el cuestionamiento del postulado, que durante mucho tiempo los historiadores del pensamiento y de la cultura solian dar por bueno, de que existe un origen histórico definido para cada teoria, ideología o tipo de discurso. La nueva metodología ha hecho tambalearse cualquier certidumbre al respecto. Entre otras razones porque, como advierte Chartier, asumir esa idea de origen supone "una búsqueda sin fin de los comienzos [...] que anula la originalidad del acontecimiento [o del texto, o del pensamiento, en nuestro caso], que se supone presente incluso antes de su advenimiento [o de su escritura]." ${ }^{\prime 96}$

Marc Bloch previno a los historiadores contra "la obsesión embriogénica" y "el ídolo de los orígenes", que busca "la explicación de lo más próximo por lo más lejano." ${ }^{197}$ En el límite esta obsesión conduce a la búsqueda de una suerte de "código genético" del fenómeno estudiado, al presumir la existencia de un núcleo esencial más o menos remoto que se iría desplegando teleológicamente en las distintas fases de su desarrollo.

Tras dejar de lado con buenos argumentos aquella supuesta "tradición absoluta" consistente en el imaginario diálogo atemporal entre un conjunto de grandes pensadores debatiendo a través de los siglos sobre un corto número de "cuestiones perennes", la renovada historia intelectual debe ahora hacer frente a la falacia opuesta: la de la "innovación absoluta" que imagina un origen identificable y datado para cada corriente de pensamiento. Los estudios históricos más atentos a la historicidad del lenguaje tienden a mostrar, por el contrario, que en historia del pensamiento raramente es posible determinar unos orígenes perfectamente claros y delimitados para cualquier ideosistema de cierta complejidad. Más descabellado aún sería pretender que esos orígenes contenían in nuce desde el principio una especie de programa orientado al desarrollo completo de esta 0 aquella religión o ideología -pensemos en el cristianismo o en el liberalismo, por ejemplo- tal como hoy las conocemos.

Para la historia intelectual no habria pues ni tradiciones imperecederas ni tampoco comienzos absolutos. La "falacia genealógica" -que convierte en necesidad la contingencia, y presenta como una trayectoria coherente lo que fue un manojo inconexo de fenómenos heterogéneosempieza por admitir contra toda evidencia que cada cosa, cada concepto, cada ideología tiene un "origen histórico" reconocible. Esta práctica académica -equivalente a la proyección sistemática de los conceptos hacia el pasado a que he aludido en varias ocasiones en este texto- conduce a la creación de una entidad fantasmagórica que trata de hacer pasar como un fenómeno histórico "real" lo que no es más que una construcción discursiva del historiador. 
98

FREEDEN, Michael. Ideologies and Political Theory: A Conceptual Approach. Oxford: OUP, 1996. _. Ideología. Una breve introducción, Santander: Universidad de Cantabria, 2013; __ The Political Theory of Political Thinking. The Anatomy of a Practice. Oxford: OUP, 2013.
Consideraciones finales: Ideologías y tradiciones electivas

Sin caer en esa exagerada retórica de la innovación académica que he criticado más arriba, quisiera enfatizar que las dos escuelas hoy en dia hegemónicas en el escenario internacional en este área -cada vez más hibridadas- han contribuido, cada una a su manera, a un tratamiento mucho más satisfactorio de los problemas de la innovación y la tradición en historia intelectual. Ciertamente la Begriffsgeschichte de Koselleck pone más énfasis en la diacronía, mientras que la historia conceptual al estilo de Skinner prefiere ajustar el foco sobre los cambios en el plano sincrónico (actos de habla, redescripción retórica, etc.), y por tanto en la innovación ideológica. Es la diferencia que va de una perspectiva histórico-semántica, como la alemana, a otra más bien históricopragmática, como la que predomina en el mundo anglófono (sobre todo en su versión skinneriana). Creo sin embargo que, más allá de estas y otras diferencias de énfasis y de culturas académicas, ambos enfoques comparten algunas importantes asunciones teóricas sobre la naturaleza del lenguaje y sobre la historicidad de las formaciones intelectuales. $Y$, entre esos supuestos fundamentales, a mi modo de ver unos y otros sostienen visiones mucho más fértiles y refinadas acerca de cómo tratar desde la historia intelectual el complejo binomio tradición/modernidad de lo que los métodos de la vieja historia de las ideas y los toscos esquematismos procedentes de las teorias de la modernización de la segunda postguerra nos tenían acostumbrados.

Junto a estas dos aproximaciones y a los instrumentos de conocimiento e interpretación de las formaciones político-intelectuales del pasado a ellas asociadas (y también a otras aproximaciones más recientes, como el análisis histórico-morfológico propuesto por Michael Freeden), ${ }_{1}^{98}$ el enfoque de las "tradiciones electivas" que he defendido en este trabajo podría arrojar luz sobre determinados aspectos de la historia de las ideologías y de los movimientos políticos y sociales en los últimos siglos. Me refiero a aspectos que quedan en sombra, o no se perciben suficientemente, desde las mencionadas perspectivas (y resultan completamente opacados desde las ópticas más tradicionales de la historia de las ideas o de la filosofía política).

El estudio del liberalismo, del republicanismo, del socialismo o de cualquier otra corriente ideológica o movimiento político contemporáneo podria beneficiarse grandemente, en efecto, de una aproximación histórico-discursiva como la que aquí proponemos, centrada en el análisis de la gestación de sus relatos de origen, así como de los procesos de historización específica del correspondiente -ismo por parte de sus líderes y fundadores. Para ello convendría prestar una atención muy especial a la elaboración y puesta en pie de "tradiciones electivas" que los sostenedores de dichas corrientes político-intelectuales crearon e hicieron suyas, en especial durante la etapa de lanzamiento de la ideología en cuestión (generalmente en un plazo relativamente breve de tiempo).

Pensemos en el liberalismo, por ejemplo. En lugar de tomarlo como una línea de pensamiento inmemorial que se confundiria en el límite con la civilización occidental (H. Laski), o incluso como una corriente originada en Inglaterra a finales del siglo XVII con la publicación del Segundo tratado sobre el gobierno civil de Locke, perfeccionada luego por un selecto grupo de autores eminentes (Montesquieu, Smith, Burke, Constant, Mill e tutti quanti), podríamos verlo sencillamente como un macroconcepto (clusterconcept) y una nueva tradición de pensamiento forjados por los liberales $-\mathrm{y}$ 
Hemos intentado aplicar en parte este nuevo enfoque, combinado con el de una historia conceptual comparativa, al estudio de los liberalismos iberoamericanos nacientes, tanto en el Diccionario de lberconceptos como en el volumen colectivo. FERNÁNDEZ SEBASTIÁN, Javier (Dir.) Diccionario politico y social del mundo iberoamericano. La era de las revoluciones, 1750-1850. Madrid: CEPC, 2009. p. 693-848; . (Ed.) La aurora de la libertad. los antiliberales- en el transcurso de las luchas políticas euroamericanas de la primera mitad del ochocientos.

Se tratará de estudiar, entonces, con todo detalle cómo, en qué circunstancias y en virtud de qué estrategias retóricas, fue surgiendo ese "liberalismo virtual" anterior a los liberales, imaginado por ellos para justificar su acción y legitimar sus fines políticos, aunque muy pronto un cierto número de filósofos e historiadores -casi siempre liberales-, tomando aquellos relatos y tradiciones selectivas por oro de ley, procedieran ya desde 1820 a construir ese liberalismo imaginario de los siglos XVII y XVIII (o incluso de épocas anteriores) que aparece en tantas historias clásicas del liberalismo como el verdadero origen del mismo. Apenas es preciso decir que, desde nuestro punto de vista, dicho liberalismo avant la lettre -que extrañamente preexiste a los liberales- es una construcción filosófica e historiográfica, más que una realidad histórica.

La perspectiva de las "tradiciones electivas" asume, por el contrario, que fueron los primeros liberales de carne y hueso quienes, en la segunda década del siglo XIX -no antes-, empezaron a imaginar, en sus particulares contextos a un tiempo locales y "globales", una doctrina/corriente/tradición que vagamente etiquetaron como "liberalismo". Lo hicieron partiendo de las experiencias y de los textos que tenían a mano, dando forma poco a poco a sus grandes esperanzas y expectativas. Tras los primeros tanteos, a partir de lecturas muy variadas y de sus contactos con extranjeros y exiliados, fueron seleccionando un censo de sus autores favoritos y un relato canónico. De ahí que sin ser exactamente los mismos en Lisboa y en Londres, en Madrid, París, Filadelfia, México o Río de Janeiro, con los años los "liberales" de varios países, de dos continentes, alcanzaran un notable grado de consenso sobre las fuentes, raices e hitos compartidos por ese "liberalismo clásico" euroamericano, conformado fundamentalmente por unos pocos autores británicos y franceses y por algunos eventos revolucionarios destacados ocurridos en el Atlántico norte que en cierto modo servían de modelo y fijaban la pauta para todos los demás.

Ahora bien, si dejamos a un lado ese famoso canon liberal, que ha llegado a adoptar los rasgos estilizados de un tipo ideal, y optamos por una historia político-intelectual alternativa, más apegada a la vida política real, más centrada en el lenguaje de los agentes y en la reconstrucción de los desafíos teóricos y prácticos que las gentes del pasado hubieron de afrontar en contextos concretos, seguramente lograremos entender mejor aquellos liberalismos realmente existentes en ciertos lugares y momentos del pasado. ${ }^{99}$ En suma, esos serían mucho más los liberalismos empíricos, diversos, rugosos e impuros del historiador, en lugar de "el liberalismo" abstracto, pulido y desencarnado de los filósofos y de los historiadores de la filosofía. Lo cual, entre otras cosas implicaría una redefinición sustancial del marco temporal de referencia. Por continuar con el ejemplo, la fecha de aparición en España del primer partido liberal (finales de 1810) pasaría de terminus ad quem a terminus a quo. En lugar de arrancar de Locke, Montesquieu, etc. y seguir, aguas abajo, el juego de la "influencia" de su pensamiento sobre los liberales hispanos de comienzos del XIX como si del curso y desembocadura de un caudaloso río se tratase, habría que situarse de entrada en Cádiz en 1810 y mirar, aguas arriba, hacia las múltiples fuentes y arroyuelos en los que abrevaron aquellos primeros liberales ibéricos para buscar soluciones a sus problemas concretos en circunstancias políticas dadas, e idear un futuro halagüeño. $Y$, desde aquel entonces, poner de re- 
100

Empezando por el liberalismo, primera ideologia-movimiento de la modernidad decimonónica. Sabemos que la palabra liberalismo empezó a usarse en español en 1813, en francés en 1818 y en inglés en 1819. Veamos algunos otros ejemplos. Socialisme se usó desde 1832 en francés, desde 1837 en inglés, desde 1840 en español. Republicanism, en inglés, desde 1680; en francés, desde 1750; en español, desde 1793. Démocratisme, en francés desde 1794; en español, desde 1812. Progresismo empezó a usarse muy esporádicamente en español desde 1839; en francés, desde 1842; en inglés, desde 1855. Conservatism se documenta en inglés desde 1835; en francés, desde 1851; en español, desde 1882. lieve las vías por las que aquellos pioneros liberales comenzaron a pensarse a sí mismos insertos en el curso de un largo devenir -viéndose, por ejemplo, como continuadores de los comuneros castellanos del siglo XVI, de los ilustrados del siglo XVIII, etc.-; una mirada optimista que, inspirada en la filosofía del progreso, les llevó a desarrollar diversas especulaciones históricas sobre el origen, el pasado, el presente y el porvenir de la idea liberal, así como sobre sus padres fundadores y sobre su rápido desarrollo hacia futuras metas.

Un expediente similar podria aplicarse a la historia del republicanismo, del socialismo y de las demás ideologías contemporáneas. Interesaría entonces determinar, por una parte, cuándo y bajo qué circunstancias se acuñó el término para designar a cada uno de esos "conceptos de movimiento." ${ }^{100}$ Y sobre todo cómo fue creciendo su utilización, mientras que a la palabra en cuestión se vincularon polémicamente una historia y una serie de tradiciones (no pocas veces apócrifas, y frecuentemente alternativas), hasta formar un haz que agrupaba, junto a ciertos principios y bases doctrinales, un selecto repertorio de hechos y personajes, autores y obras considerados canónicos y definitorios de tal movimiento o ideología (no solo por sus seguidores, sino en muchas ocasiones también por los historiadores que, sobre los pasos de aquellos, han dado cuenta de la historia de esas ideologías).

El desarrollo de un programa de investigación de este tipo, a caballo entre la historia conceptual, la historia de la historiografía y la historia de las prácticas discursivas, permitiría un acercamiento histórico mucho más rico y matizado a las ideologías-movimientos políticos, en su doble faceta de "tradiciones electivas" y de realidades históricas. De su progresiva implementación cabría esperar unas historias del liberalismo, del republicanismo, del socialismo, etc. bastante diferentes de las que solemos encontrar en los estantes de nuestras librerias. Unas historias más críticas, menos tributarias de los grandes esquemas de la filosofía política, menos dependientes de los relatos que los propios liberales, republicanos o socialistas elaboraron acerca de sí mismos, de su presunto pasado y de su esplendoroso porvenir. 